\title{
A Comparison of Relative Humidity between Two Swedish Buildings with Different Ventilation Solutions
}

\author{
Thomas Alsmo, Catharina Alsmo \\ Library Research, Olten, Switzerland \\ Email: administrator@libraryresearch.eu
}

Received 24 February 2016; accepted 16 May 2016; published 19 May 2016

Copyright (C) 2016 by authors and Scientific Research Publishing Inc.

This work is licensed under the Creative Commons Attribution International License (CC BY). http://creativecommons.org/licenses/by/4.0/

c. (i) Open Access

\section{Abstract}

This project is based on measurements of the parameter relative humidity, RH (\%), in two buildings: one with natural ventilation and one with mechanical ventilation. Both buildings are located in central Sweden, which constitutes a representative climate zone with respect to Swedish conditions. An important factor for the indoor environment, which affects human health and well-being, is the level of the relative humidity, RH (\%). Research studies show that the healthiest level should be in the range of $40 \%-60 \%$. Surveys have revealed that about $70 \%$ of the employees at Swedish offices, schools and kindergartens experience that the air is too dry during the winter season. Previous studies show that the level of relative humidity in the indoor environment influences the prevalence of respiratory infections and allergies. The purpose of this study is to investigate how the relative humidity differ between the two buildings, and if this may be a cause of the health problems that users are affected by. During many years, users have complained about the environment in the building with mechanical ventilation and that they suffer from health problems. The method used in the study is air measurements of the two parameters, relative humidity and air temperature in the two buildings using data loggers. The indoor environment is affected by the outdoor climate and therefore instruments are placed outdoors to record seasonal variations. The measurements were carried out during the period October 2014 to September 2015 to include all of Sweden's four seasons with completely different climatic conditions. The results of this study show that the relative humidity in the mechanically ventilated building is consistently significantly lower than in the building with natural ventilation whatever the time of year and temperature indoors. This study shows that mechanical ventilation in buildings affects the indoor environment negatively with respect to human health during most time of the year and this fact must be taken into consideration for the existing as well as the planning of new ventilation systems.

\section{Keywords}

Hygiene, Hygiene and Health, Air Quality, Sick Building Syndrome (SBS), Particle Implication, 
Particle Measurements, Indoor Environment; Indoor Humidity, Indoor Temperature, Particle Size, Particle Amount, Physical Environment

\section{Introduction}

This project is based on measurements of the parameter relative humidity, RH (\%), in an office building. During many years, users have complained about the conditions in the indoor environment in the building and that they suffer from health problems. These health problems are considered to be related to deficiencies in the building's technological status. The relationship between the parties involved is in many situations difficult with differing views on how to handle the situation and the measures to be taken. Extensive investigations have been conducted and as well public health facilities, at both regional and local levels, as experts with extensive experience in this type of problem have been engaged. Despite this, no unified plan has been developed for a chance to resolve the problems. In autumn 2013, the property owner launched an action program within the framework of the Swedish authorities' directives about how this type of project should be handled. With regard to this, it has still been difficult to continue to pursue the matter. Among the users, there are those who regularly stay in the concerned premises and experience severe health problems. In addition to these effects, there is concern in the workplace. The property owner's proposed measures to correct the deficiencies have not been taken into account by those who represent the users.

An important factor for the quality of the indoor environment, which affects human health and well-being, is the level of relative humidity, RH (\%). Studies have shown that about $70 \%$ of the employees at Swedish offices, schools and kindergartens feel that the indoor air is too dry during the winter season [1]. Studies show that the level of relative humidity in the indoor environment influences the prevalence of respiratory infections and allergies. These studies show that the key factors for a healthy indoor air environment are:

1) to limit the number of the airborne particles since they are carriers of both bacteria, viruses, and allergen;

2) the relative humidity is at a level above $40 \%$ and below $70 \%$, which has the effect that the survival of viruses and bacteria is minimized [2].

A survey focused on those directly involved in the office building, reveals that $72 \%$ of the employees experience that the indoor air is too dry during the winter months. The corresponding figure for the summer months is $40 \%$ [3].

\section{Humidity and Health Impacts}

The requirement for a "suitable thermal climate" is a commonly formulated functional requirement and what temperature that can be accepted must be assessed for each situation. A normal level of indoor air temperature in Sweden should be at least $20^{\circ} \mathrm{C}$ so that the total comfort indoor climate should be considered acceptable. Disorders and discomforts of cooling cannot be assessed solely by measurements of air temperature, since the perceived temperature will depend on several factors. Those climatic factors are in addition to air temperature, radiant temperature, air velocity and humidity. High indoor temperatures correlate with both the outdoor climate and the construction of the building, but also the heat that the activity itself generates. In offices, lighting and computer equipment are normally the operational heat sources that create the largest increment of heat. The high moisture content of the air in the summer makes it even more difficult to get rid of excess body heat. Buildings with a light body, low room height, small rooms and poorly insulated roof structures and with large windows without shading and air vents places in the sun, causes the temperature to rise quickly indoors. Unpleasant solar radiation through windows can be limited with various types of solar shading [4].

The humidity is a measure of the amount or proportion of water vapor that the air contains. It can be specified as either:

- absolute humidity, where the actual amount of water vapor is indicated, or as

- relative humidity, where the proportion of water vapor are relative to the maximum possible amount of water vapor at a certain temperature, known as the saturation vapor content, see Figure 1.

In this project we study the relative humidity, RH (\%). In epidemiological studies, the researchers have examined the relationship between the number of respiratory infections and the relative humidity in offices, homes and schools. The incidence of respiratory infections were found to be lower among people who work or live in 
environments with a relative humidity level between $40 \%$ and $70 \%$, in comparison with those who live in environments with a relative humidity level below or above this level. An overview of the relative humidity shows that the negative health effects can be minimized by maintaining a relative humidity of $40 \%$ and below $60 \%$. The effect of relative humidity, with respect to biological and chemical factors, is graphically summarized in Figure 2. The shape and height of the bars in Figure 2 indicate an increase or a decrease in power and provides no quantitative data. Most of the illustrated negative health effects increase in severity over $60 \%$ and/or below $40 \%$ relative humidity. The exceptions are the chemical interactions that consistently increase over $30 \%$, and the conditions that produce ozone, which is constantly increasing in severity with a drop in relative humidity. A reduction in morbidity and possibly mortality from influenza is an important factor for increasing the relative humidity from low to middle [2]. Within the framework of this project, a literature review was conducted. The results of this review demonstrate the substantial health problems in both too high and too low relative humidity

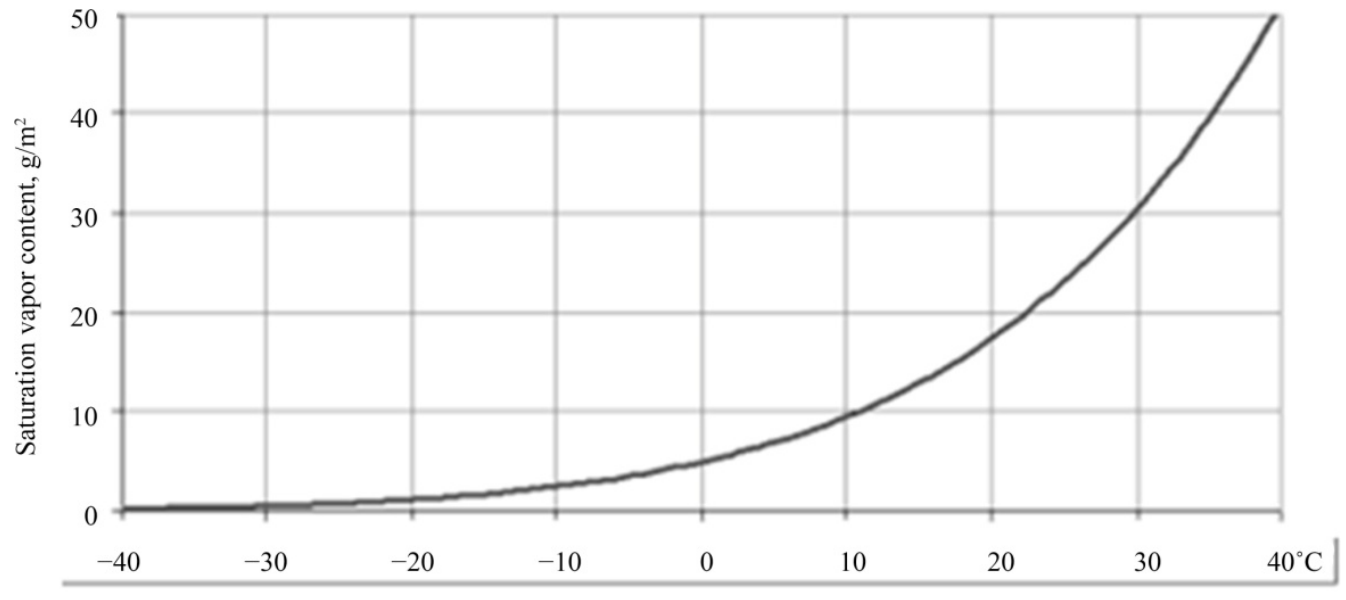

Temperature, ${ }^{\circ} \mathrm{C}$

Figure 1. The graph shows the relationship between the saturation vapor content $\left(\mathrm{g} / \mathrm{m}^{3}\right)$ and temperature $\left({ }^{\circ} \mathrm{C}\right)$. It should be pointed out that the air generally contains a certain limited amount of water and at lower temperature the water content is further gradually reduced, see the graph in the diagram.

DECREASE IN BAR WIDTH

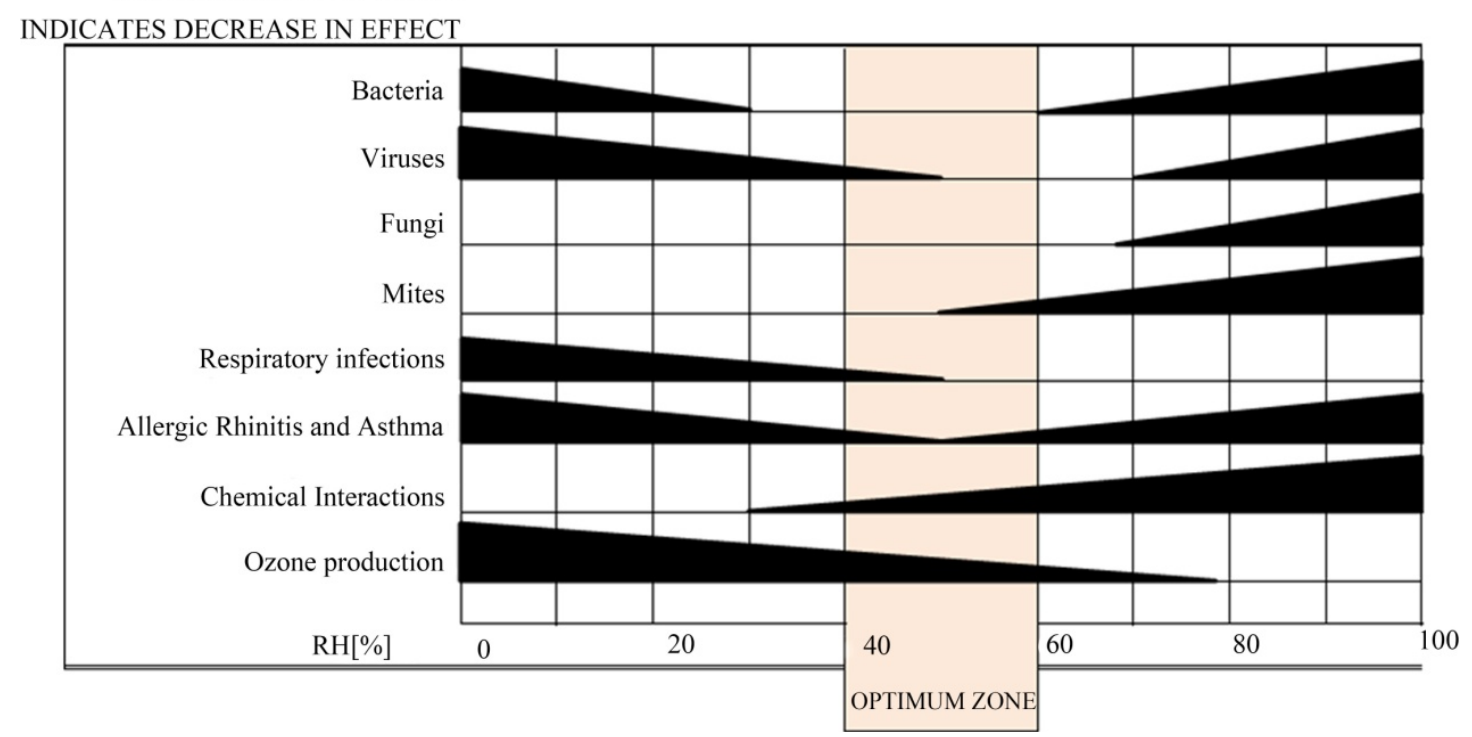

Figure 2. The effect of relative humidity, on biological and chemical factors, is graphically summarized above. The optimum zone is in the range between $40 \%-60 \%$ relative humidity to minimize the negative health effects of common air pollutants [2]. 
indoors [5]-[38].

The relative humidity may vary very much over the day and the indoor air is perceived to be dry when it is below 30\%. Dry air tends to be more common in colder climates because the air cannot hold the moisture and it folds out (condenses) [39]. Regarding the relative humidity in indoor environments, the range for normal indoor temperatures of $19^{\circ} \mathrm{C}-27^{\circ} \mathrm{C}$, there are both direct and indirect effects that affect health and comfort. There may be physical discomfort at both low and high relative humidity [40]. Extremely low levels, below 20\%, may cause eye irritation [41] [42], while moderate or high levels of humidity have been shown to reduce the degree of difficulty for people with asthma [43]. Several reports indicate that:

- patients are bothered by dryness of the nose and throat where low relative humidity prevails and that

- the relative humidity indoors should be maintained above $30 \%-40 \%$ to prevent drying of the mucous membranes and to maintain adequate nasal mucus transport and ciliary activity [44]-[50].

The relative humidity also has an important direct negative effect on health when high humidity is combined with high temperatures. This combination reduces the rate of evaporative cooling of the body and can cause significant discomfort or lead to heat exhaustion, fatigue and possibly death. Diseases are transmitted either by airborne pathogens, direct contact with pathogens that live on hard surfaces such as furniture and fittings or by touching an infected person. Low relative humidity has been shown to enhance the survival of rhinoviruses and influenza viruses [51] and human rotavirus (a cause of gastroenteritis) on hard surfaces [52]. Experimental studies on the survival of pathogens in the air with different relative humidity rate and epidemiological studies of respiratory infections, suggest that the relative humidity indoors affect the incidence of infectious diseases transmitted by airborne pathogens. Rapid evaporation in dry air can cause the diameter of some aerosols to reduce below the size limit for a particle to remain in suspension*, while at higher relative humidity, the same aerosol reach the floor before sufficient evaporation occurs [53] [54]. An increase in the amount of suspended aerosols, as a result of relatively low humidity is more likely to have an effect on health than the reduction of these during periods of very high relative humidity. Experimental studies have shown that the relative humidity is an important factor for the survival of airborne pathogens and affects the survival by altering the integrity of the cell wall or the viral cover [55].

$$
\text { *Suspension }=\text { slurry of solid particles in a liquid. }
$$

\section{Measurements}

All measurements of humidity assume that there is an upper limit to the humidity, which depends on temperature and pressure. If you then either add more water vapor (moisture) or lower the gas temperature, the amount of water vapor eventually exceed this maximum and the excess precipitates as water droplets $=$ condensation, see Figure 1. The instruments used in this study are the Testo 175, data logger, which has two channels for each relative humidity and air temperature with internal and external sensor connection. The stored measured values are evaluated by software and both programming and reading of the instrument is made to the computer via a USB connection. This study includes measurements of relative humidity, $\mathrm{RH}(\%)$ and air temperature, ${ }^{\circ} \mathrm{C}$ for two types of buildings, one with mechanical ventilation and one with a natural ventilation design. In the mechanically ventilated building people have for many years complained about the indoor environment. The measurements were carried out at seven locations in the mechanically ventilated building, where two representative measuring sites are presented in this report. In the building with natural ventilation, measurements were taken at three sites, including one representative test site in this report. Both buildings are located in central Sweden as a representative climate zone for Swedish conditions. The purpose of the study is to examine, compare and evaluate if any difference can be identified regarding the relative humidity in these two buildings as a result of various ventilation solutions. The measurement period covers the period from October 8th, 2014 to September 24th, 2015, which includes all the seasonal variations that occur in Sweden. The measurement instruments have continuously collected data with a frequency of every two hours. The total number of measured values for the period is 4200 pieces per measurement site and parameter. The climate outdoors is the basis of the status of the indoor environment and therefore measurements are also carried out in the outside air that surrounds each affected building.

From previous measurements in school buildings, the results show that the relative humidity is affected by the building's ventilation system. From a health aspect the mechanically ventilated buildings are significantly unhealthier for the users than buildings with natural ventilation systems, see Figure 3. In the building with natural 


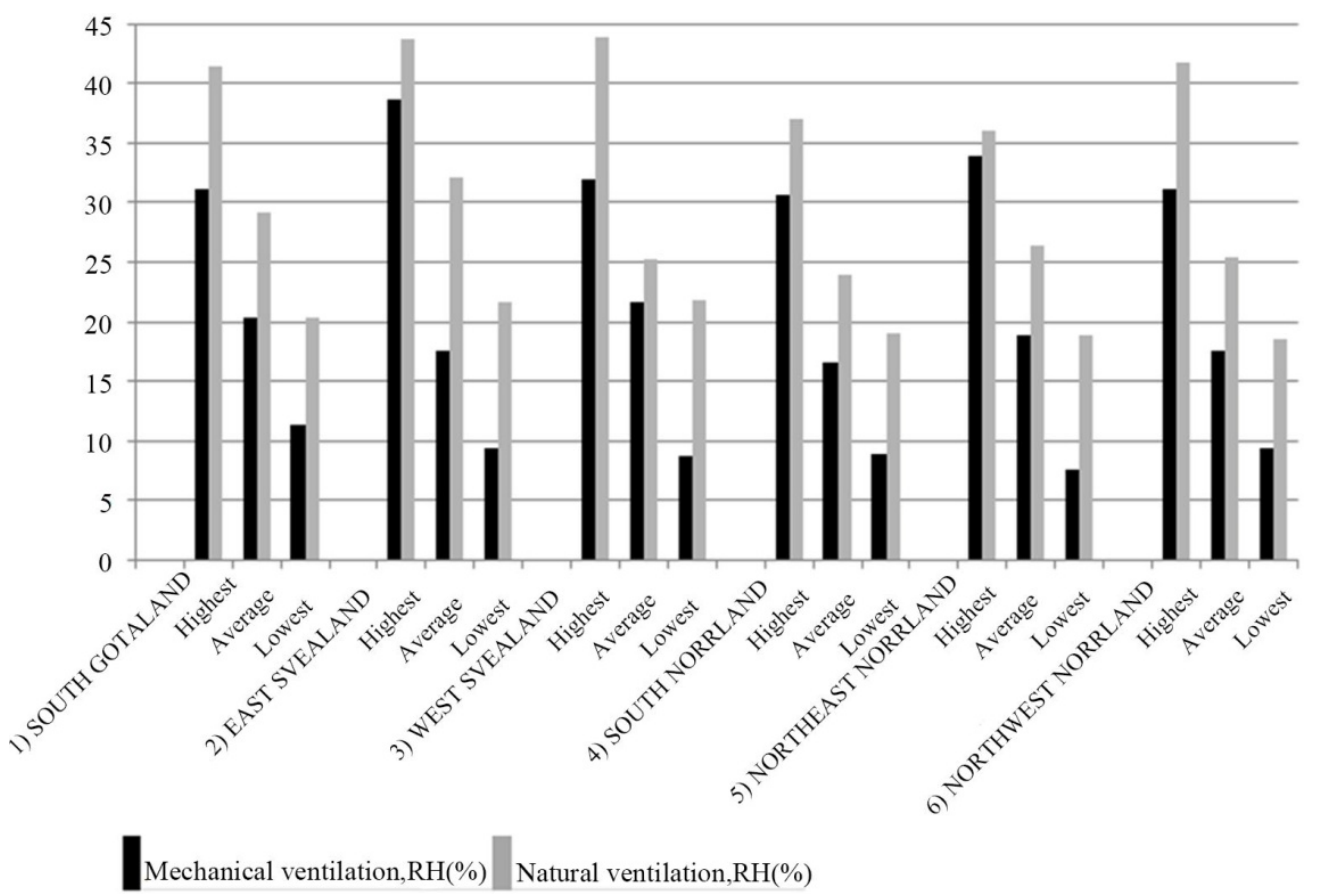

Figure 3. The graph shows the relative humidity, RH (\%) in 12 buildings, 6 with mechanically ventilated systems and 6 with natural draft. The buildings, one of each category, are distributed at locations in Sweden that includes the different climate zones with the following test sites: 1) South Gotaland; 2) East Svealand; 3) West Svealand; 4) South Norrland; 5) North East Norrland; 6) North West Norrland. The measurement period runs from 10-24 January 2014, a winter period and the diagram shows the average values as well as the highest and lowest measured values for each building. The results clearly show that the relative humidity, $\mathrm{RH}(\%)$ in mechanically ventilated systems in all cases is lower than in the corresponding case for natural ventilation systems [56].

ventilation the humidity level rises during the day when there're activities in the building. Compared with a similar situation in mechanically ventilated buildings, it happens that the level even further decline during the daytime, see Figure 4 and Figure 5 [56]. Calculations of average values of relative humidity regarding public health are in this context misleading.

- In buildings with natural ventilation systems the humidity level is higher when people are staying there;

- In mechanically ventilated buildings the humidity level is lower when there are people in the building.

Here we have identified a problem. The relative humidity during the day should be higher in mechanically ventilated buildings due to human presence, than during the night when there is no one in the building. However, as shown in Figure 4 and Figure 5, the humidity level drops in buildings with mechanical ventilation when the activities start. The only explanation for this is that the ventilation flow was increased from substantially reduced flow rates up to $100 \%$ efficiency.

\section{Results}

Generally, there was a fairly mild winter season 2014/2015 with a continuous period of freezing temperatures from the end of November/December to mid-March. For a few days at the end of December 2014, there was a strong cold spell. The measurements show that the temperature outdoors permanently increases from February until the summer period June to August, when the temperature level is more stable around $20^{\circ} \mathrm{C}$. The relative humidity outdoors is stably higher than $80 \%$ during the winter period, until the end of February and then more frequently fluctuate between $20 \%$ and $100 \%$. At the end of the measurement period, in September 2015, the level is more regularly over $60 \%$. The results from the measurements outdoors, see Figure 6. The graphs in Figures 7-18 report humidity levels indoors and regarding the indoor temperature there are small variations over shorter periods. This is likely caused by various temporary changes in the indoor environment and climate change, outdoor, temperature variations, influence of the sun etc. Regarding the air temperature in the buildings, it is at the levels expected prevailing in this type of environment. The measurement results indoors show that 


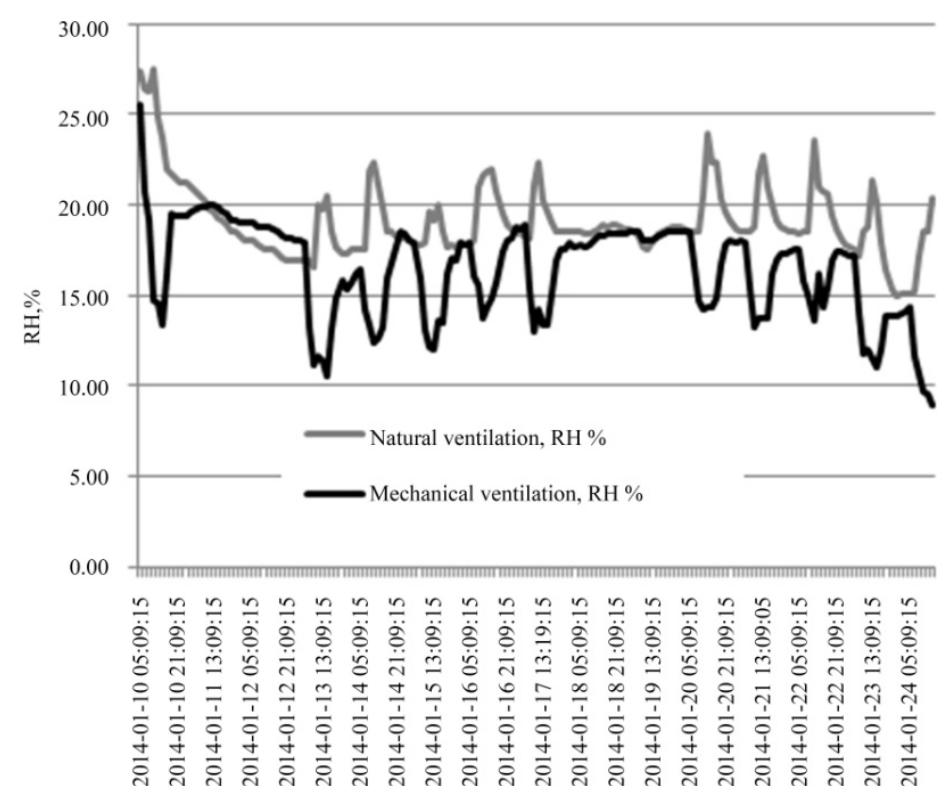

Figure 4. Measurement results of humidity, RH (\%), for the measurement period January 10 to 242014 in the buildings in Figure 3, at measuring location 4, southern Norrland, in one of the buildings with mechanical ventilation and in one of the buildings with natural ventilation. The graphs show that humidity varies during the day when there's activity going on in the buildings. When the classroom is staffed the relative humidity, RH (\%), raises with the natural ventilation system, while this effect is not achieved in the classroom with the mechanical system where the air instead further dries out. The only explanation for this is that the ventilation flow was increased from 0 or from reduced flow to $100 \%$ efficiency [56].

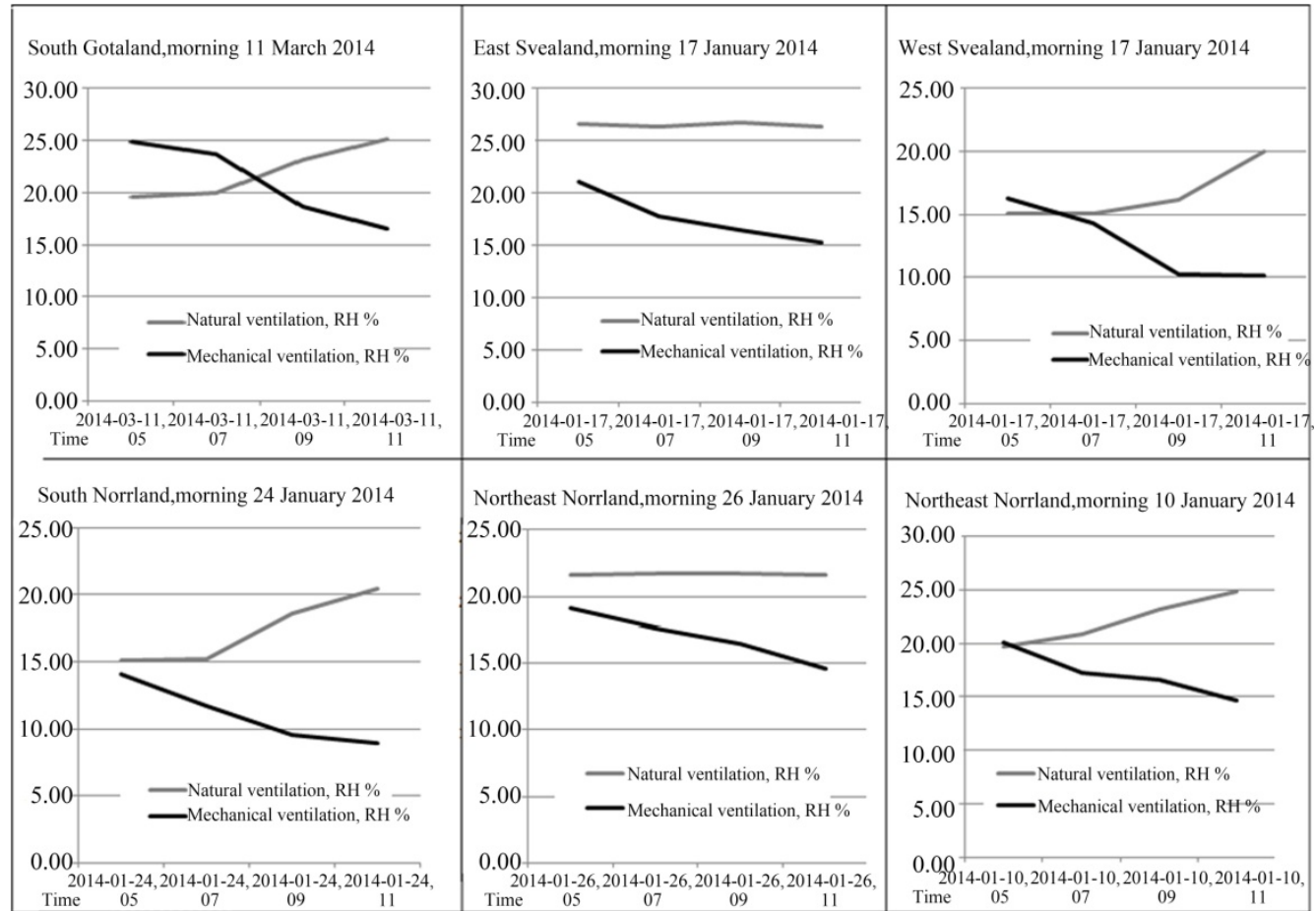

Figure 5. Measurement results of humidity, RH (\%), in the same buildings as in Figure 3, one morning during the period January 10 to 24,2014 . The graphs show that the humidity is different during daytime, the same way as in Figure 4 . In natural ventilation buildings the level raised, unlike the situation in the mechanically ventilated buildings where the level fell further. There is activity in both buildings during the day, which should add humidity to the air, but instead as shown by the black dots in the diagrams, the level decreases in these buildings. The only explanation for this is that the ventilation flow was increased from 0 or from reduced flows to $100 \%$ efficiency [56]. 


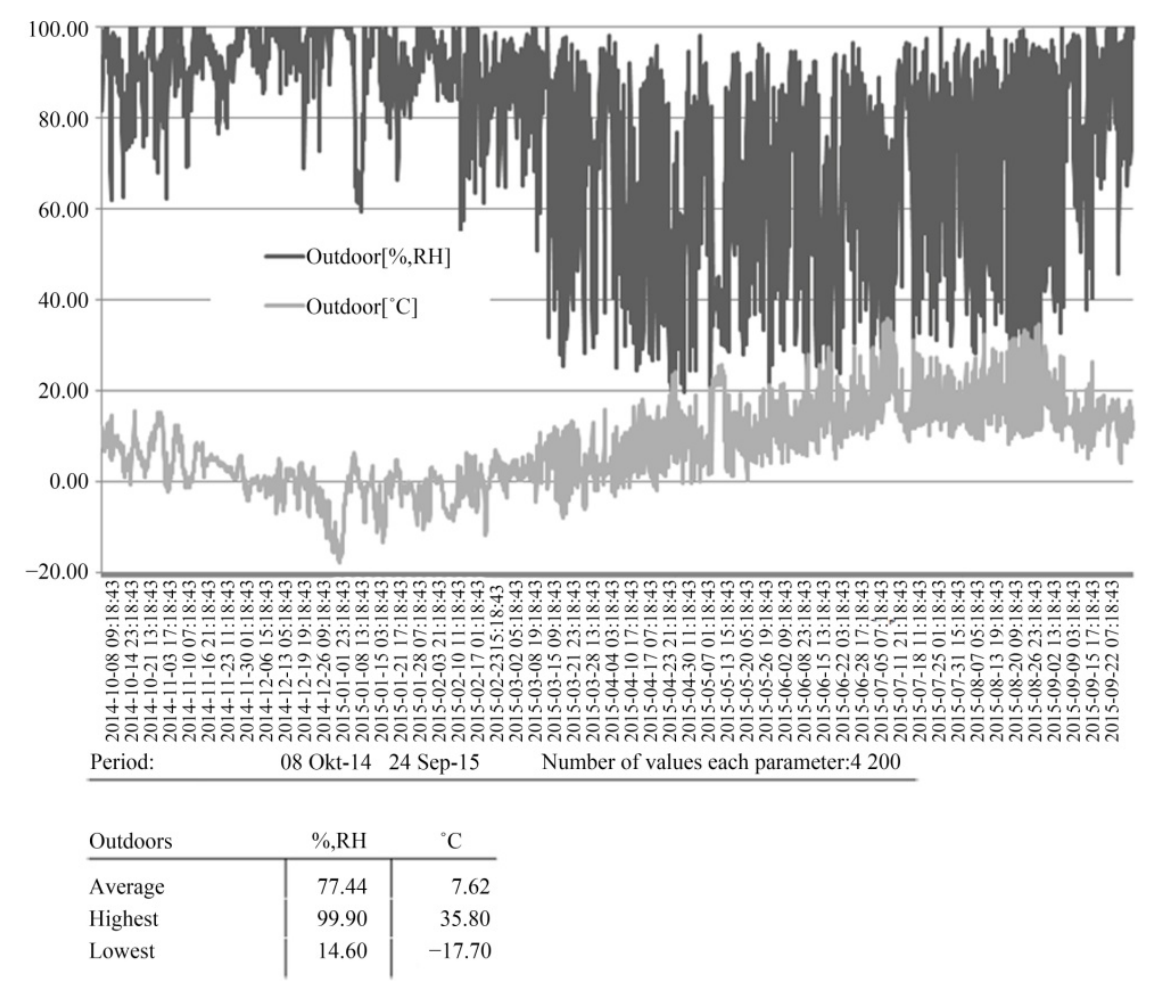

Figure 6. The relative humidity, RH (\%) and the outdoor temperature for the period 8 October 2014-24 September 2015, at a site in central Sweden.

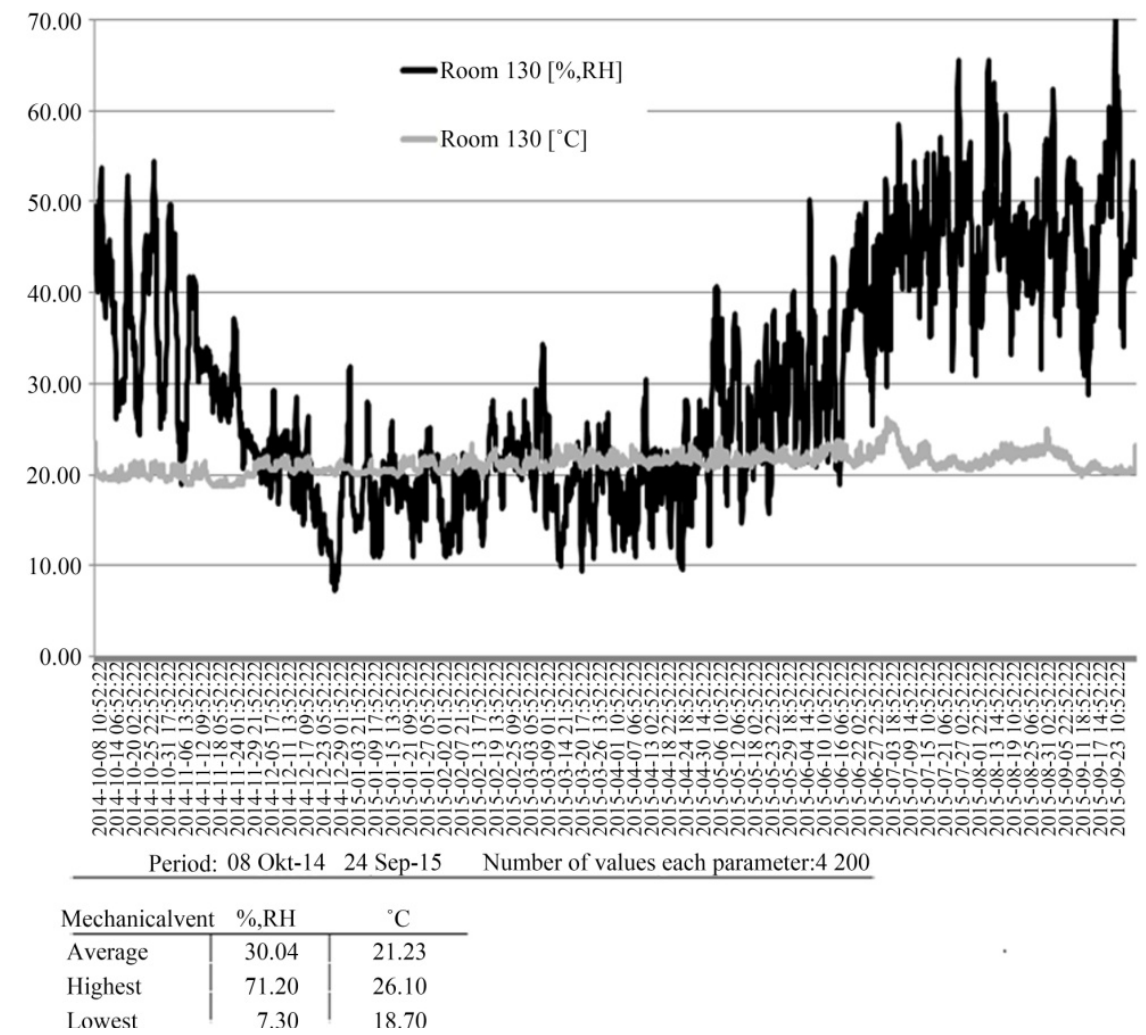

Figure 7. The relative humidity, RH (\%), and temperature in the building with mechanical ventilation for the period 8 October 2014-24 September 2015. The building is located in central Sweden. 


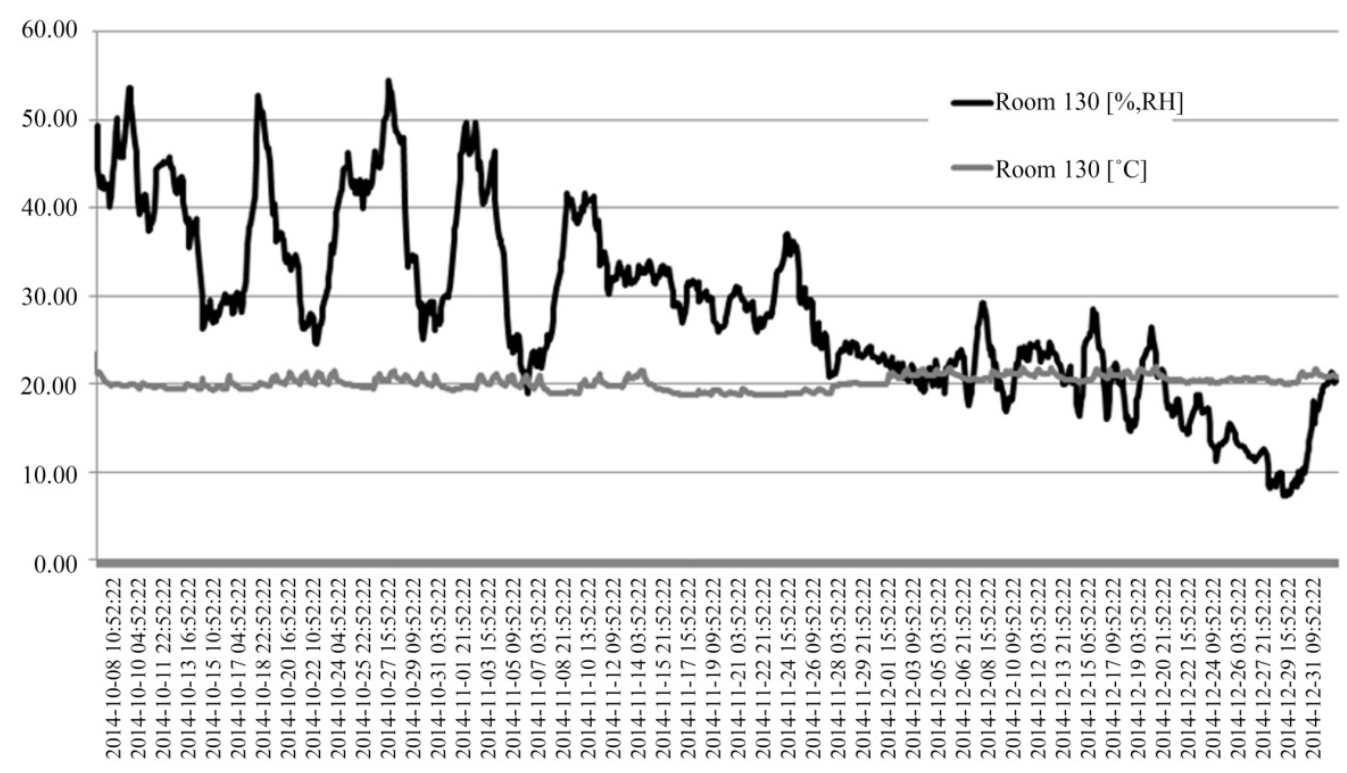

Period: 08 Okt-14 31 Sep-14 Number of values each parameter:1 000

\begin{tabular}{lr|r}
\multicolumn{1}{c}{} & \multicolumn{1}{c}{$\%, \mathrm{RH}$} & \multicolumn{1}{c}{${ }^{\circ} \mathrm{C}$} \\
\cline { 2 - 3 } Average & 28.58 & 20.17 \\
Highest & 54.40 & 23.60 \\
Lowest & 7.30 & 18.70
\end{tabular}

Figure 8. The relative humidity, RH (\%) and temperature in the building with mechanical ventilation for the period from October 8 to December 31 in 2014. The building is located in central Sweden.

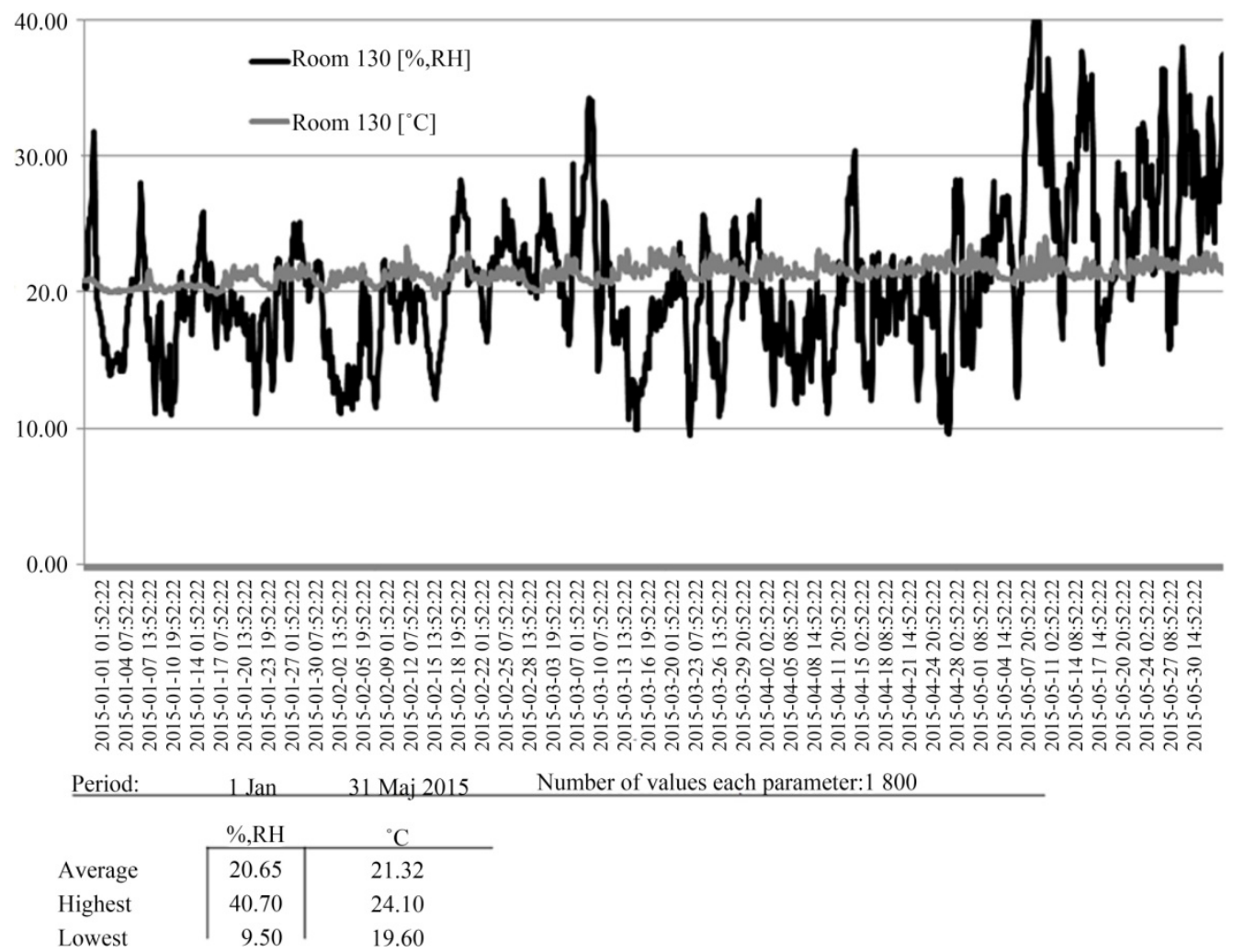

Figure 9. The relative humidity, RH (\&) and the temperature in the building with mechanical ventilation for the period January 1 to May 31, 2015. The building is located in central Sweden. 
T. Also, C. Also

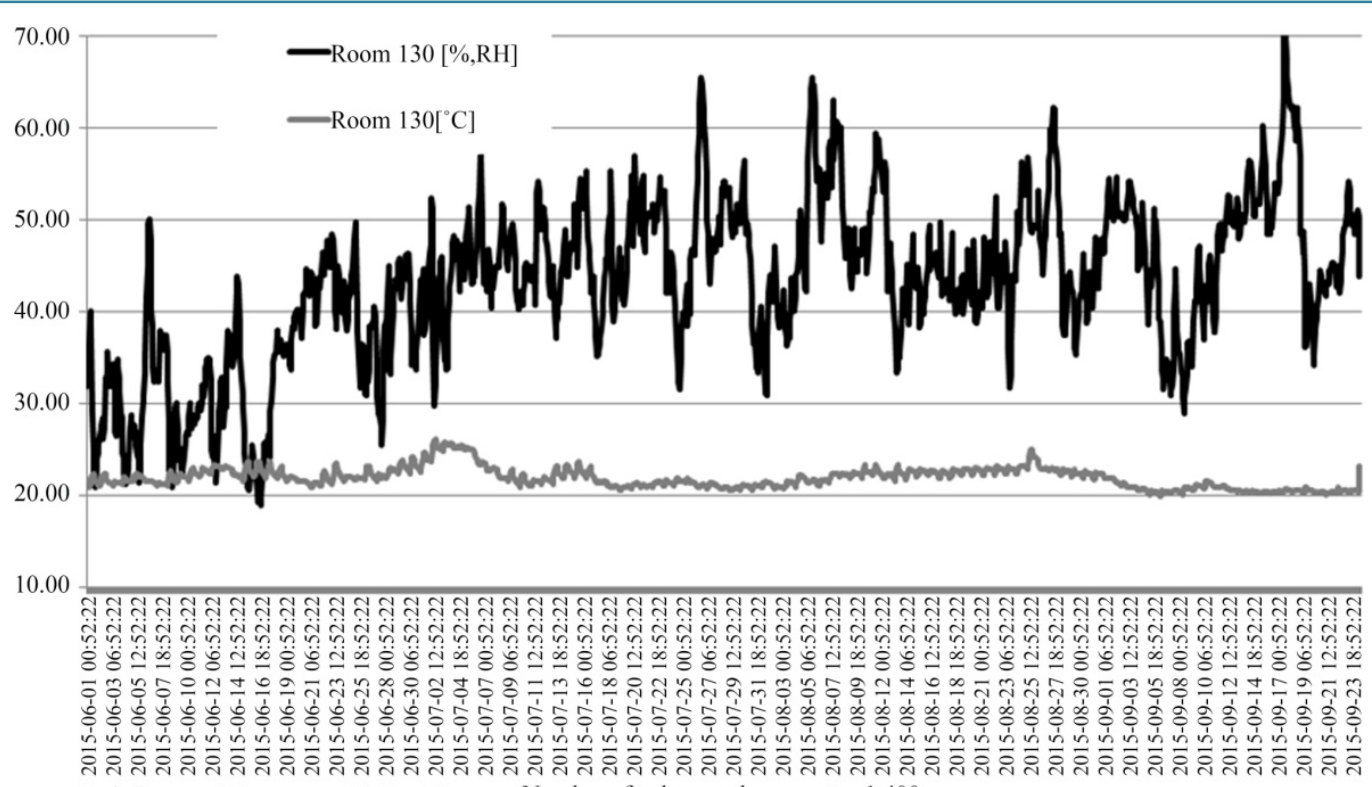

Period: 1 Jun $\quad 24 \mathrm{Sep}-15 \quad$ Number of values each parameter:1 400

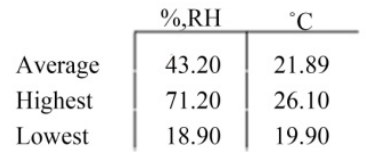

Figure 10. The relative humidity, RH (\%) and temperature in the building with mechanical ventilation for the period June 1 to September 4, 2015. The building is located in central Sweden.

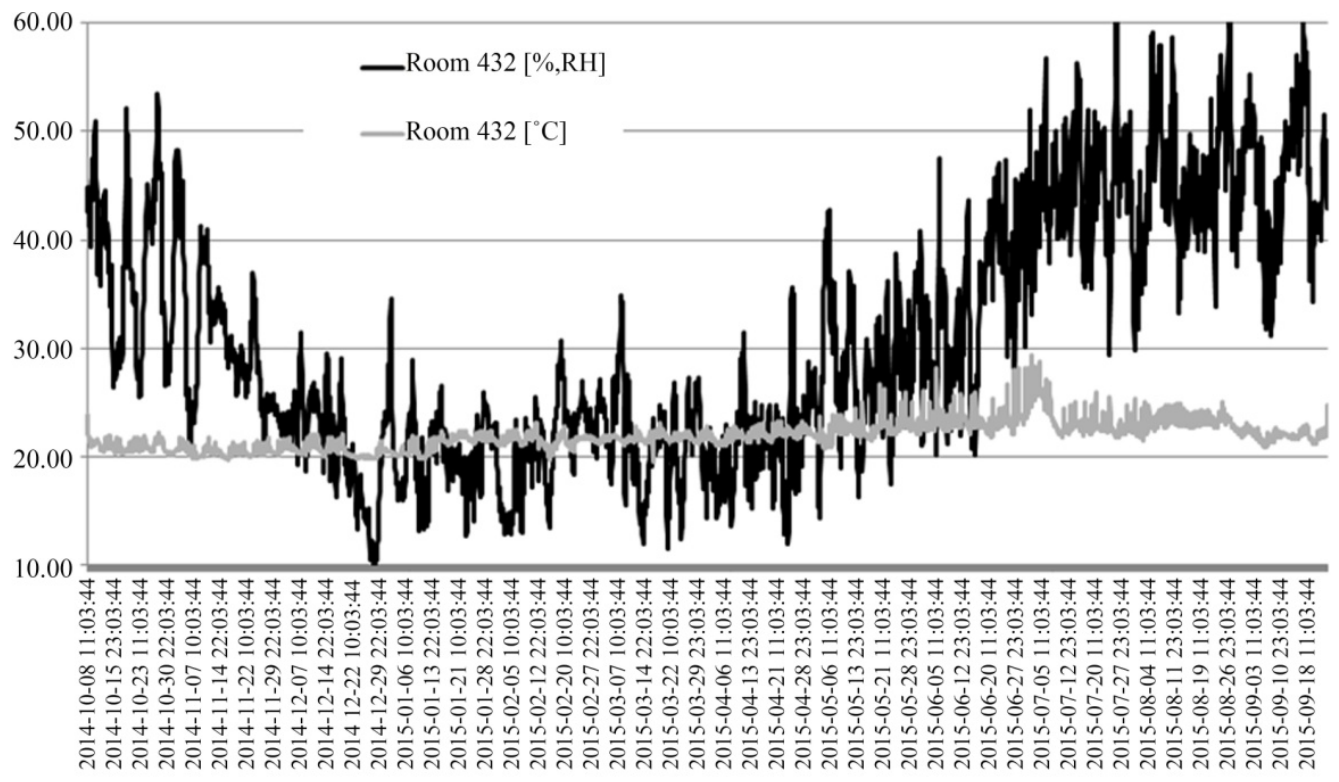

Period:

08 Okt-14 24 Sep-15 Number of values each parameter:4 200

\begin{tabular}{l|l|l} 
Mechanicalvent & \multicolumn{1}{c}{$\%, \mathrm{RH}$} & ${ }^{\circ} \mathrm{C}$ \\
\hline Average & 30.58 & 21.96 \\
Highest & 61.80 & 29.30 \\
Lowest & 9.50 & 19.60
\end{tabular}

Figure 11. The relative humidity, RH (\%) and temperature in the building with mechanical ventilation for the period from 8 October 2014-24 September 2015. The building is located in central Sweden.

(863) 


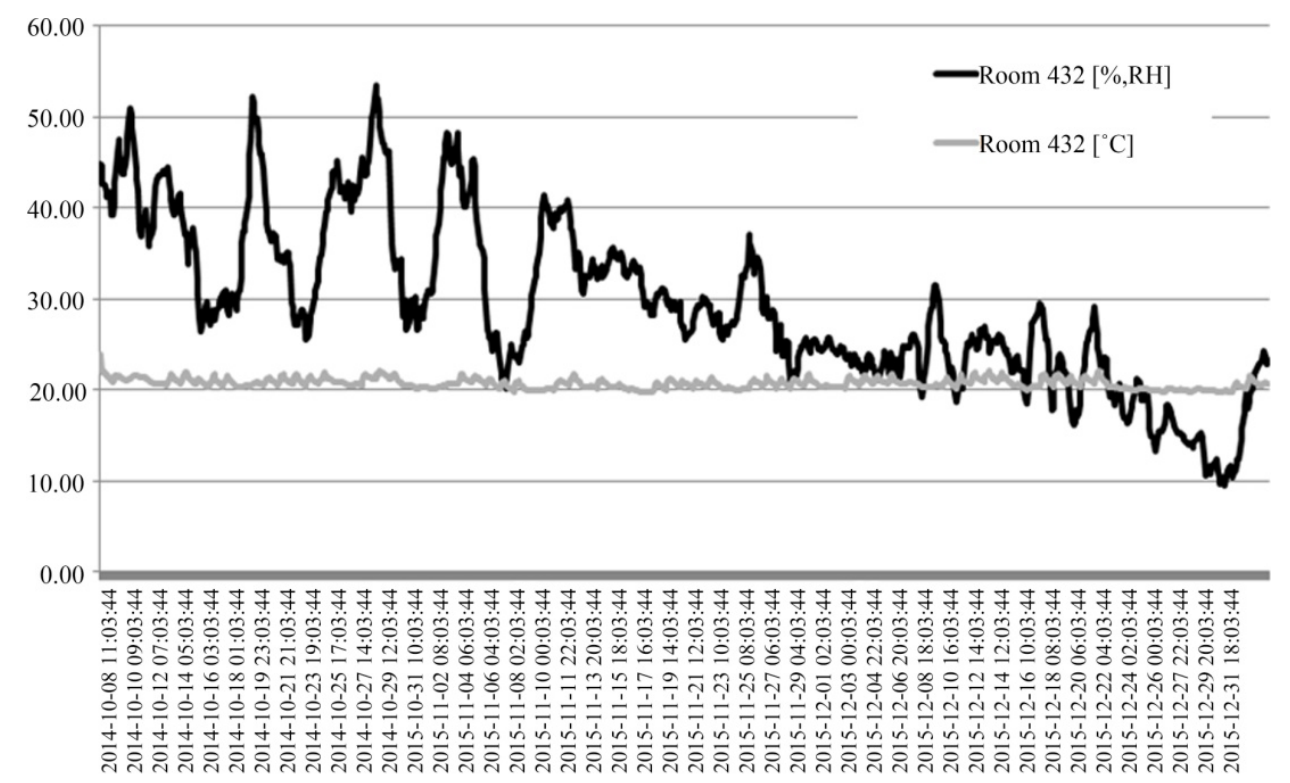

Period: 08 Okt-14 31 Dec-14 Number of values each parameter:1 000

\begin{tabular}{l|l|l}
\multicolumn{1}{c}{} & \multicolumn{1}{c}{$\%, \mathrm{RH}$} & ${ }^{\circ} \mathrm{C}$ \\
\cline { 2 - 3 } Average & 29.26 & 20.72 \\
Highest & 53.50 & 23.90 \\
Lowest & 9.50 & 19.70
\end{tabular}

Figure 12. The relative humidity, RH (\%) and temperature in the building with mechanical ventilation for the period from October 8 to December 31, 2014. The building is located in central Sweden.

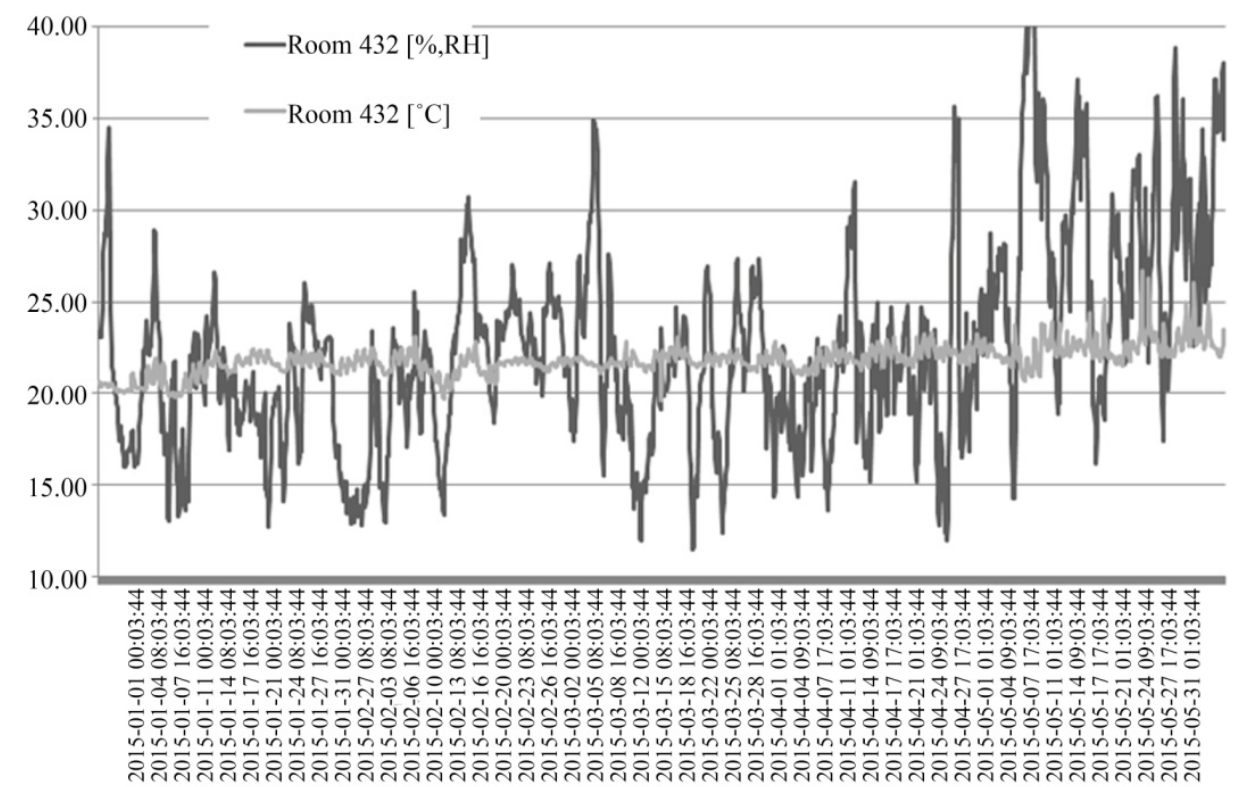

\begin{tabular}{|c|c|c|c|}
\hline Period: & $1 \mathrm{Jan}$ & 31 Maj-15 & Number of values each parameter: 1800 \\
\hline & $\%, \mathrm{RH}$ & ${ }^{\circ} \mathrm{C}$ & \\
\hline Average & 22.35 & 21.81 & \\
\hline Highest & 42.80 & 26.70 & \\
\hline Lowest & 11.50 & 19.60 & \\
\hline
\end{tabular}

Figure 13. The relative humidity, RH (\%) and temperature in the building with mechanical ventilation for the period January 1 to May 31, 2015. The building is located in central Sweden. 


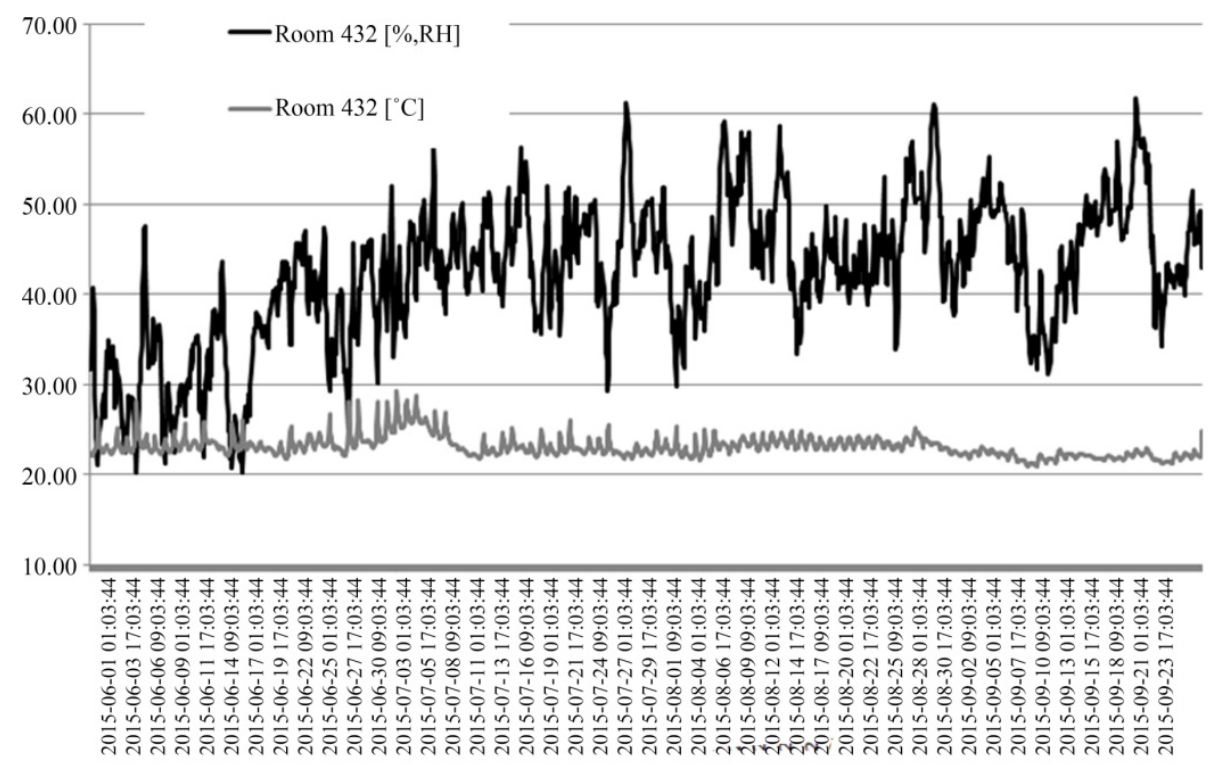

Period: $\quad 1$ Jun $\quad 24$ Sep-15 Number of values each parameter: 1400

\begin{tabular}{l|c|c}
\multicolumn{1}{c}{} & \multicolumn{1}{c}{$\%, \mathrm{RH}$} & \multicolumn{1}{c}{${ }^{\circ} \mathrm{C}$} \\
\cline { 2 - 3 } Average & 42.31 & 23.07 \\
Highest & 61.80 & 29.30 \\
Lowest & 20.20 & 20.90
\end{tabular}

Figure 14. The relative humidity, RH (\%) and temperature in the building with mechanical ventilation for the period 1 JuneSeptember 22 2015. The building is located in central Sweden.

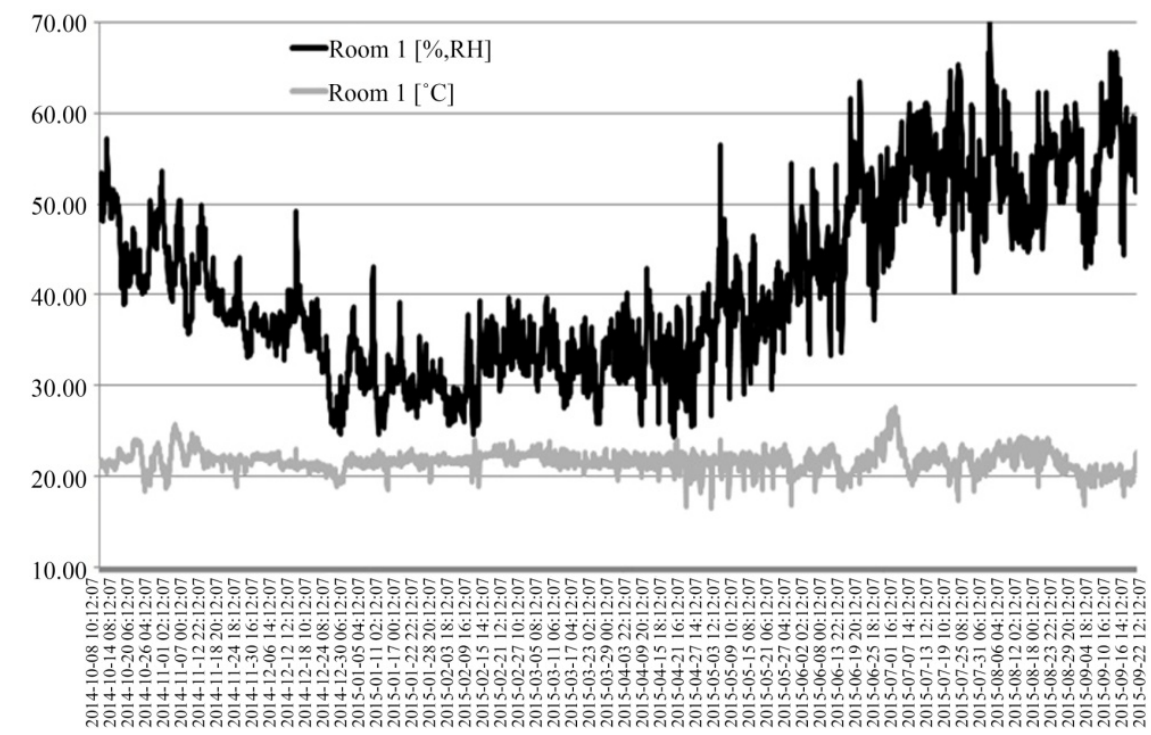

Period: $\quad 08$ Okt-14 24 Sep-15 Number of values each parameter:4 200

\begin{tabular}{l|r|c} 
Natural ventilation & $\%$, RH & \multicolumn{1}{c}{$\mathrm{C}$} \\
\hline Average & 40.98 & 21.68 \\
Highest & 72.80 & 27.60 \\
Lowest & 24.30 & 16.50
\end{tabular}

Figure 15. The relative humidity, RH (\%) and temperature in the building with natural ventilation for the period from 8 October 2014-24 September 2015. The building is located in central Sweden. 


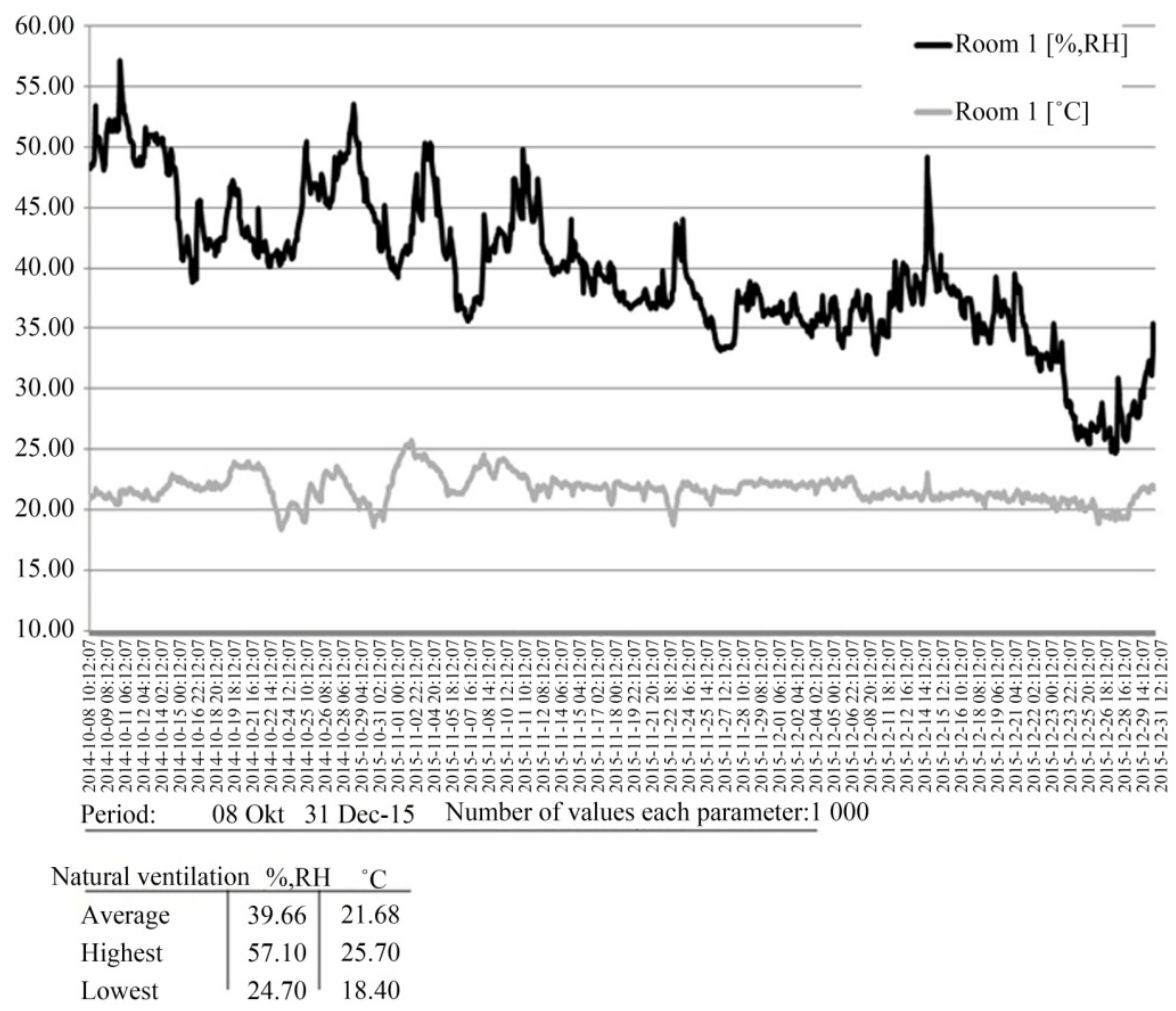

Figure 16. The relative humidity, RH (\%) and temperature in the building with natural ventilation for the period from October 8 to December 31, 2014. The building is located in central Sweden.

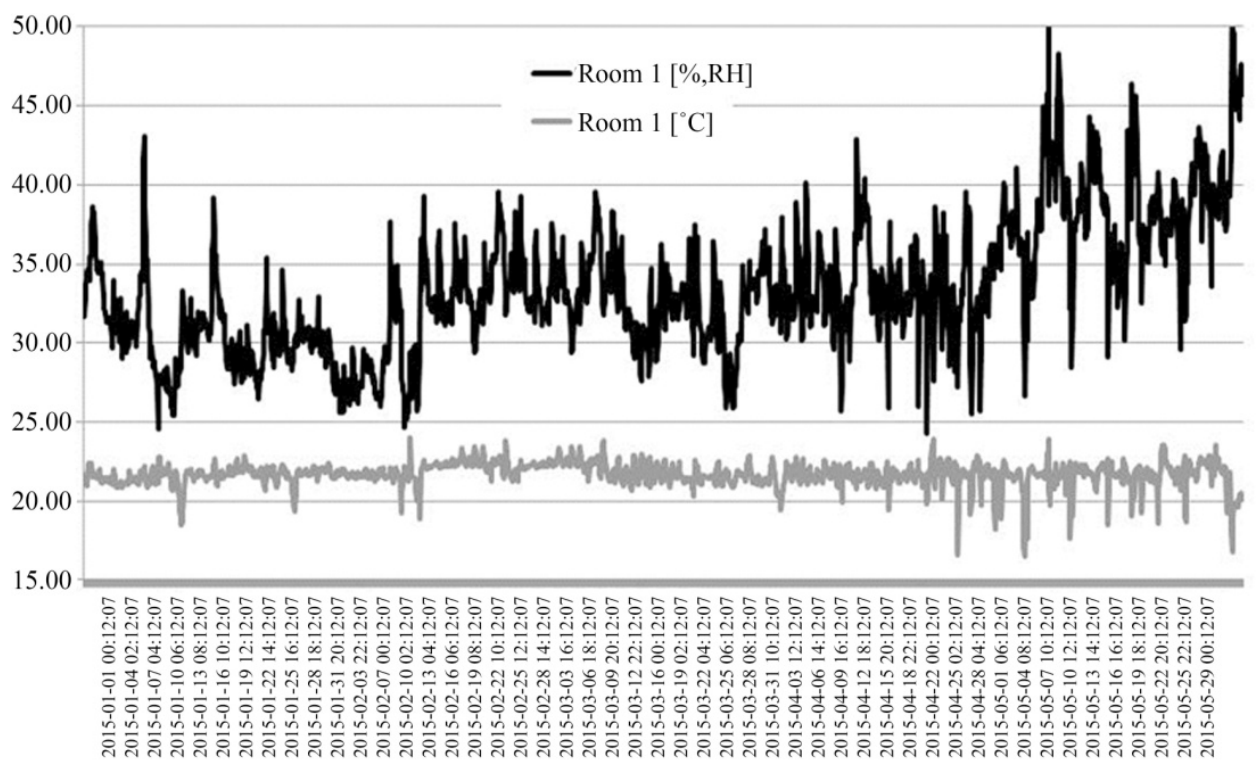

Period: 1 Jan $\quad 31 \mathrm{Maj}-15 \quad$ Number of values each parameter:1 800

\begin{tabular}{l|c|c}
$\begin{array}{l}\text { Natural } \\
\text { ventilation }\end{array}$ & \multicolumn{1}{c}{$\%, \mathrm{RH}$} & \multicolumn{1}{c}{$\mathrm{C}$} \\
\hline Average & 51.84 & 21.65 \\
Highest & 72.80 & 27.60 \\
Lowest & 33.40 & 16.90
\end{tabular}

Figure 17. The relative humidity, RH (\%) and temperature in the building with natural ventilation for the period January 1 to May 31, 2015. The building is located in central Sweden. 


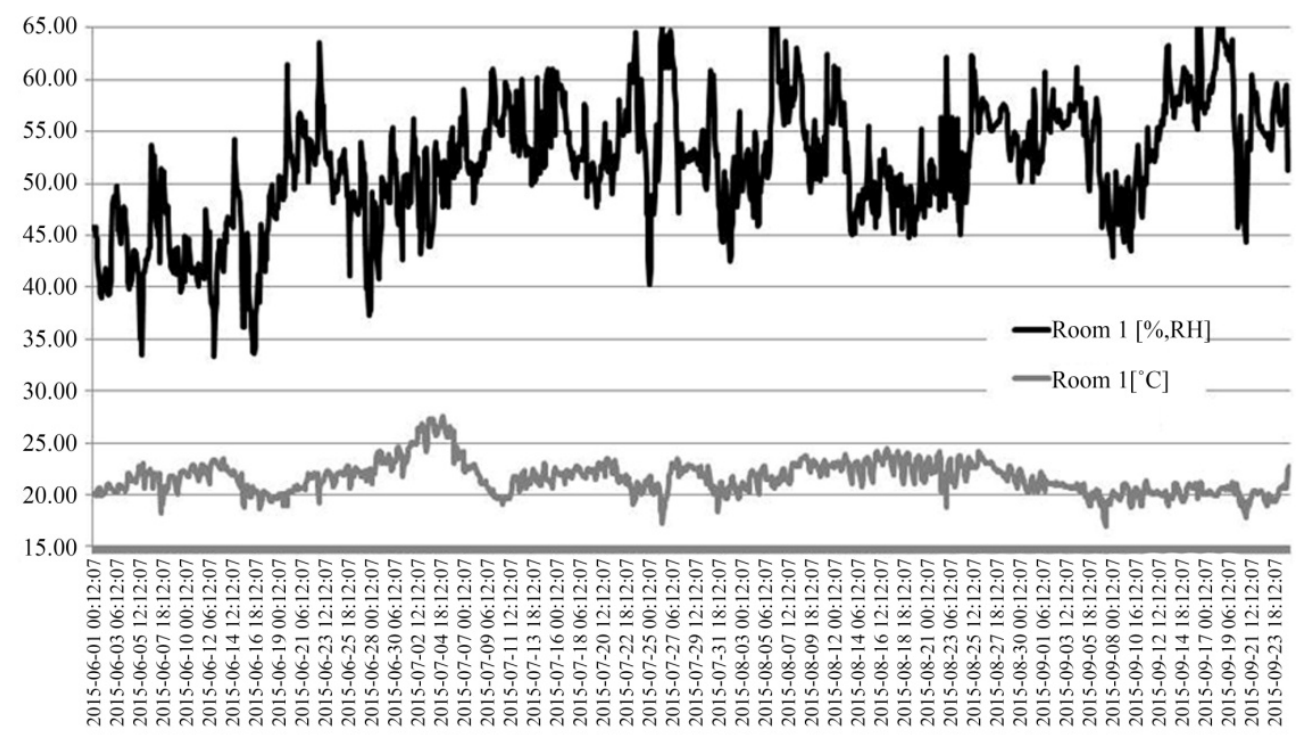

\begin{tabular}{|c|c|c|c|}
\hline Period: & $1 \mathrm{Jun}$ & 24 Sep- 15 & Number of values each parameter: 1400 \\
\hline $\begin{array}{l}\text { Natural } \\
\text { ventilation }\end{array}$ & $\%, \mathrm{RH}$ & ${ }^{\circ} \mathrm{C}$ & \\
\hline Average & 42.31 & 23.07 & \\
\hline Highest & 61.80 & 29.30 & \\
\hline Lowest & 20.20 & 20.90 & \\
\hline
\end{tabular}

Figure 18. The relative humidity, RH (\%) and temperature in the building with natural ventilation for the period January 1 to May 31, 2015. The building is located in central Sweden.

Table 1. The table below shows the average, maximum and minimum values of the relative humidity measured for the entire measurement period (A) and for three different periods (B - D).

\begin{tabular}{ccccccc}
\hline BUILDING & \multicolumn{2}{c}{ MECHANICAL VENTILATION } & \multicolumn{3}{c}{ NATURAL VENTILATION } \\
\hline Period & Average & Maximum & Minimum & Average & Maximum & Minimum \\
\hline A: 8 Oct 2014 - 24 Sep 2015 & 29.25 & 65.50 & 7.30 & 40.30 & 72.80 & 24.30 \\
B: 8 Oct - 31 Dec 2014 & 28.58 & 54.40 & 7.30 & 39.74 & 57.10 & 24.70 \\
C: 1 Jan - 31 May 2015 & 20.78 & 40.70 & 9.50 & 33.32 & 56.50 & 24.30 \\
D: 1 June - 24 Sep 2015 & 42.31 & 65.50 & 18.90 & 51.05 & 72.80 & 33.40 \\
\hline
\end{tabular}

Table 2. The table below is a summary regarding the difference in the relative humidity level, RH (\%) in time between the two ventilation systems, with RH lower than $40 \%$.

\begin{tabular}{cccl}
\hline BUILDING & MECHANICAL VENTILATION & NATURAL VENTILATION & DIFFERENCE IN TIME \\
\hline RH below $40 \%$ & 7.0 months & 5.0 months & 2.0 months $(17 \%$ of time) \\
RH below $30 \%$ & 7.0 months & 1.5 months & 5.5 months $(46 \%$ of time $)$ \\
RH below $20 \%$ & 5.0 months & 0.0 months & 5.0 months $(42 \%$ of time $)$ \\
\hline
\end{tabular}

there is generally lower relative humidity, $\mathrm{RH}(\%)$, in the mechanically ventilated building than in the building with natural ventilation. Table 1 and Table 2 show the average, maximum and minimum values of the relative humidity measured for the entire measurement period (A) and for three different periods (B - D). With regard to the previously described in Chapter 2, the relative humidity levels are low in the mechanically ventilated building and the figures in the table indicate a distinct difference from the building with a natural ventilation system.

- Average value: In the building with the mechanically ventilated system the average level of the relative humidity, $\mathrm{RH}$, is for the entire performance period $=29.25 \%$, that is, lower than $30 \%$, see line A. If we study the periods B and C, the relative humidity is $28.58 \%$ and $20.78 \%$ in two of the three periods, that is, lower 
than $30 \%$. Only during the period D, June 1 th to September 24 th, the average exceeds $40 \%$ (42.31\%). For the naturally ventilated building the average level of relative humidity doesn't drop below $30 \%$ in any of the measuring periods. For the entire measurement period, the level's for period A $40.30 \%$, B $39.74 \%$, C $33.32 \%$ and for period D $52.05 \%$.

- Minimum level: The lowest measured level of the relative humidity is below $10 \%$ in the mechanically ventilated building during two periods (B and C). Even during the summer and autumn, a period of limited heating in buildings and moisture-rich air outdoors, the RH level is below $20 \%(18.90 \%)$. For the building with natural ventilation the level is at no point below $20 \%$, and is not less than $24.30 \%$ during the three periods A - $\mathrm{C}$ and $33 \%$ for the period D.

As illustrated by the graphs in Figures 7-22 the measurement results show that there is generally low relative humidity indoors.

1) Relative humidity below $40 \%$ is an indication that health problems can affect people, see Chapter 2 . This level is crossed regularly in the beginning of October in the building with the mechanically ventilated system and is constantly below this level until the middle of June. That is, this negative situation for the indoor environment continues for seven months. There after the level is kept more frequently above $40 \%$, see Figure 7 and Figure 11. For the building with the natural ventilation system the RH level below $40 \%$ is passed in mid-November and being re-stabilized above $40 \%$ in May. That is, this situation is going on for five months, see Figure 15.

2) In the mechanically ventilated system the RH level is more regularly below $30 \%$ in mid-November. Compared with the natural ventilation system, where this occurs only at the end of December. In order to re-obtain a more stable level, that is a RH level of 30\%, this does not occur until the middle of June for the mechanically ventilated building. The corresponding ratio for the natural ventilation system takes place in mid-February. The level of relative humidity, $\mathrm{RH}<30 \%$, continues for seven months in the building with the mechanically ventilated system compared with 1.5 months in the natural ventilated building. This is a powerful indicator and the period of time that separates the two buildings is about as much as 5.5 months or $46 \%$ of the season.

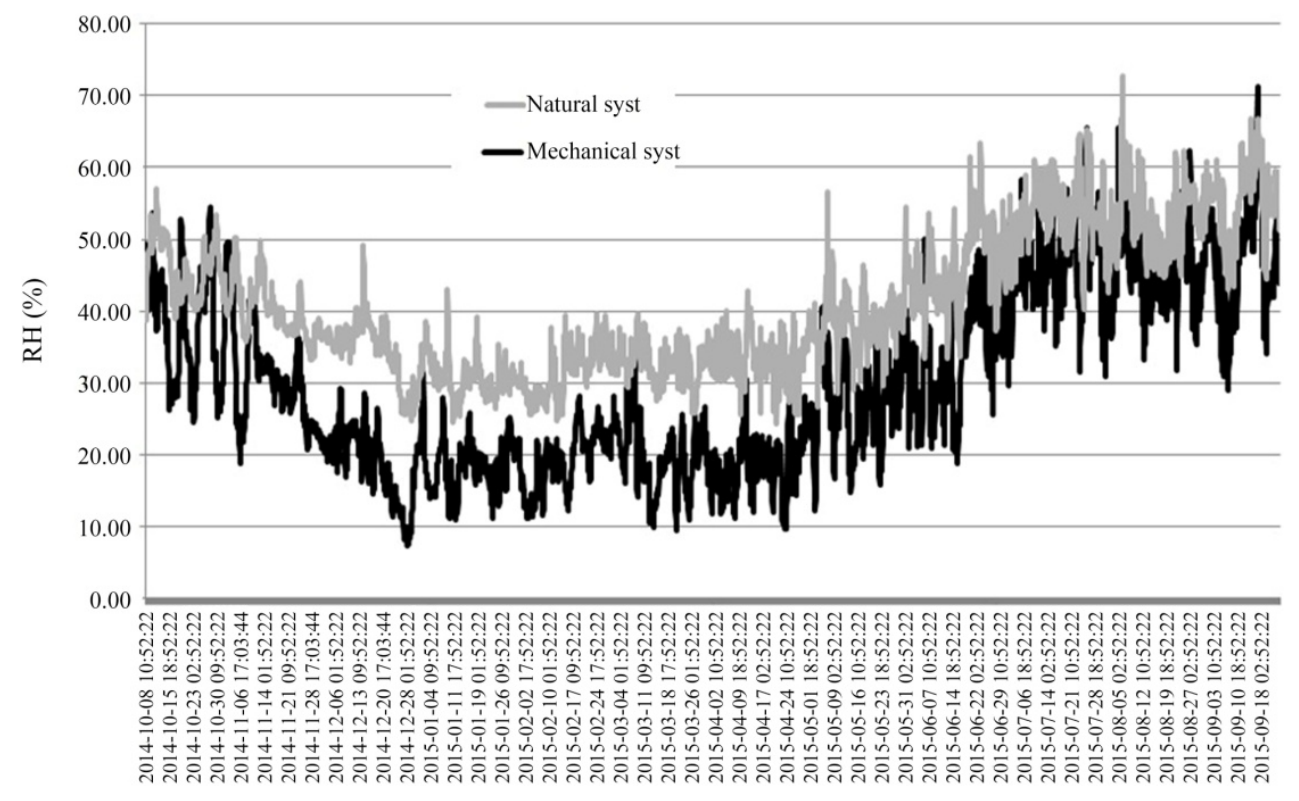

\begin{tabular}{|c|c|c|}
\hline ventilation & Mechanical & Natural \\
\hline Average & 29.25 & 40.30 \\
\hline Highest & 65.50 & 72.80 \\
\hline Lowest & 7.30 & 24.30 \\
\hline
\end{tabular}

Figure 19. Comparison of the relative humidity, RH (\%) in two buildings, one with mechanical ventilation and the other with natural draft for the period from 8 October 2014-24 September 2015. The buildings are located in central Sweden. 


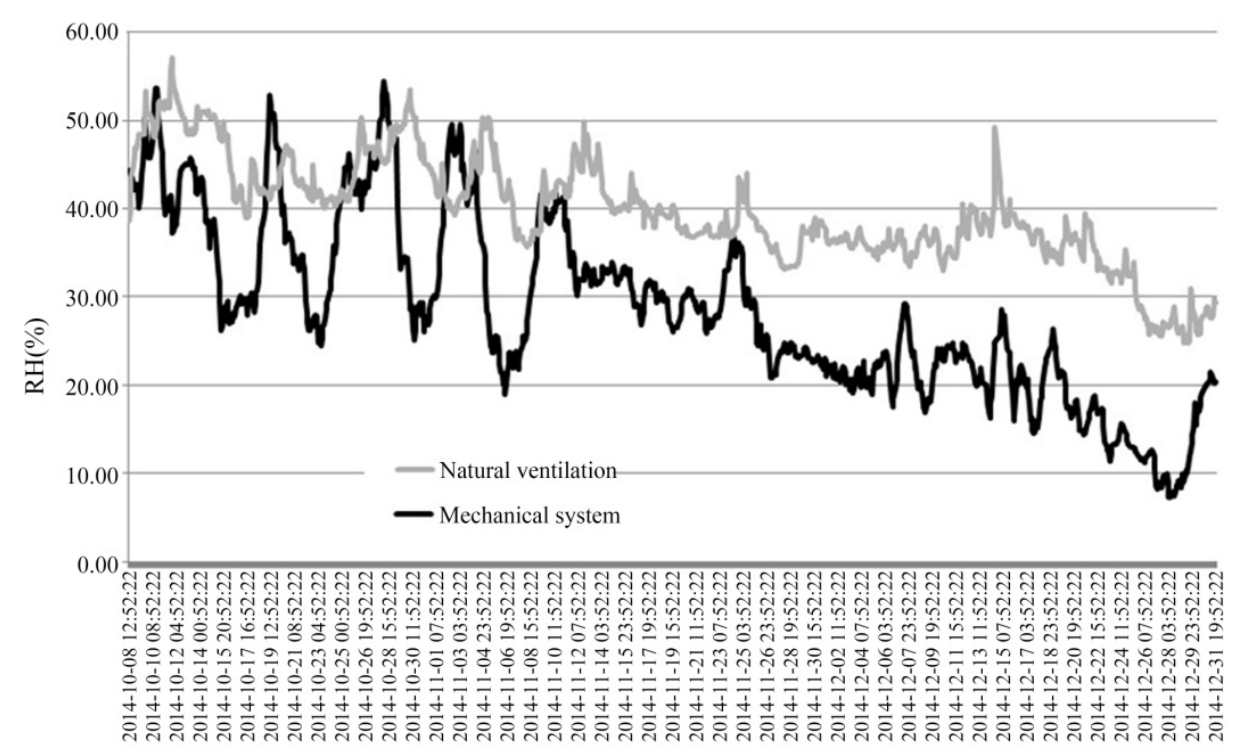

Period: 8 Okt-31 Dec 2014

Number of values each parameter: 1000

\begin{tabular}{l|c|c} 
Ventilation: & \multicolumn{1}{c}{ Mechanical } & Natural \\
\hline Average & 28.58 & 39.74 \\
Highest & 54.40 & 57.10 \\
Lowest & 7.30 & 24.70
\end{tabular}

Figure 20. Comparison of the relative humidity, RH (\%) in two buildings, one with mechanical ventilation and the other with a natural draft for the period from 8 October-31 December 2014. The buildings are located in central Sweden.

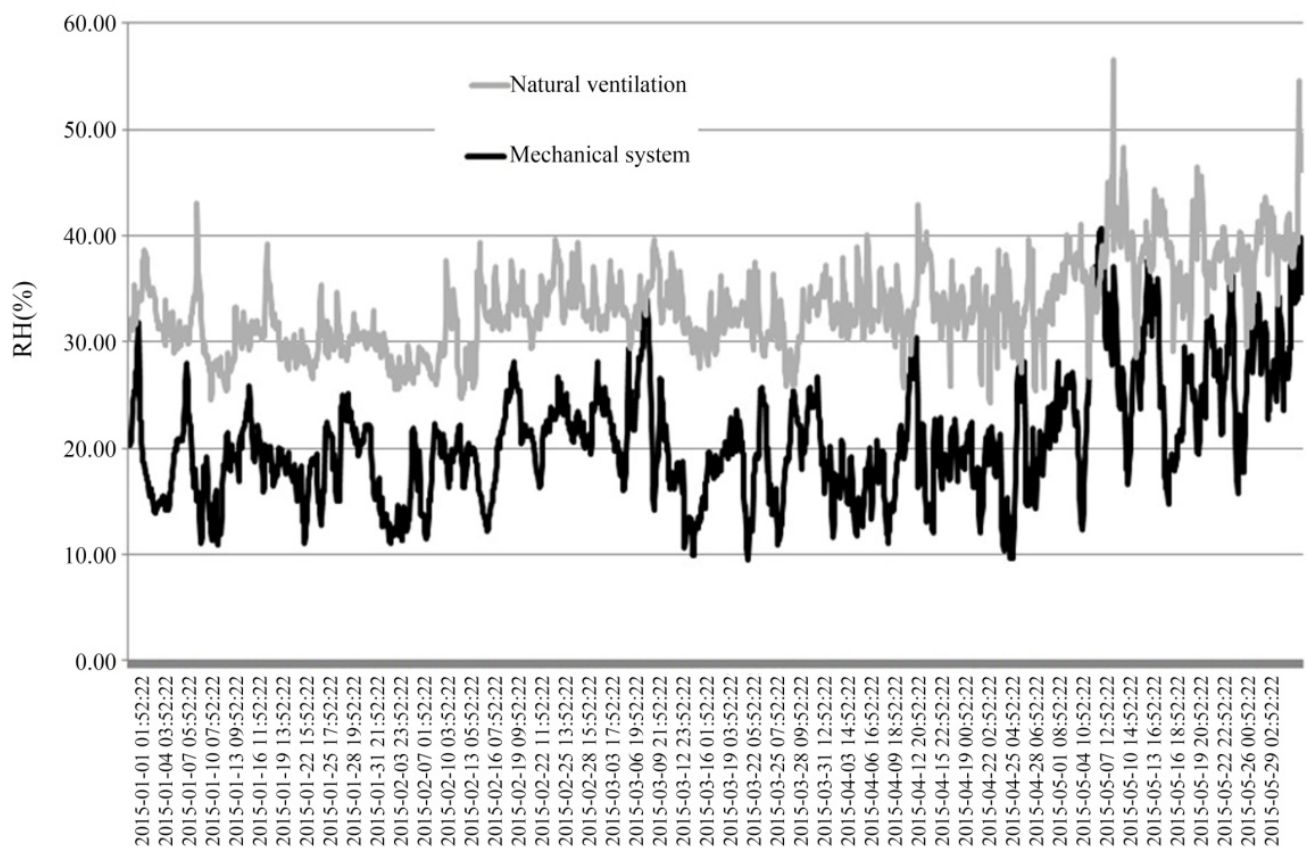

Period:1Jan-31 Maj 2015 Number of values each parameter:1 800

\begin{tabular}{l|c|c} 
Ventilation: & \multicolumn{2}{c}{ Mechanical Natural } \\
\hline Average & 20.72 & 33.32 \\
Highest & 40.70 & 56.50 \\
Lowest & 9.50 & 24.30
\end{tabular}

Figure 21. Comparison of the relative humidity, RH (\%) in two buildings, one with mechanical ventilation and the other with natural draft for the period 1 January-31 May 2015. The buildings are located in central Sweden. 


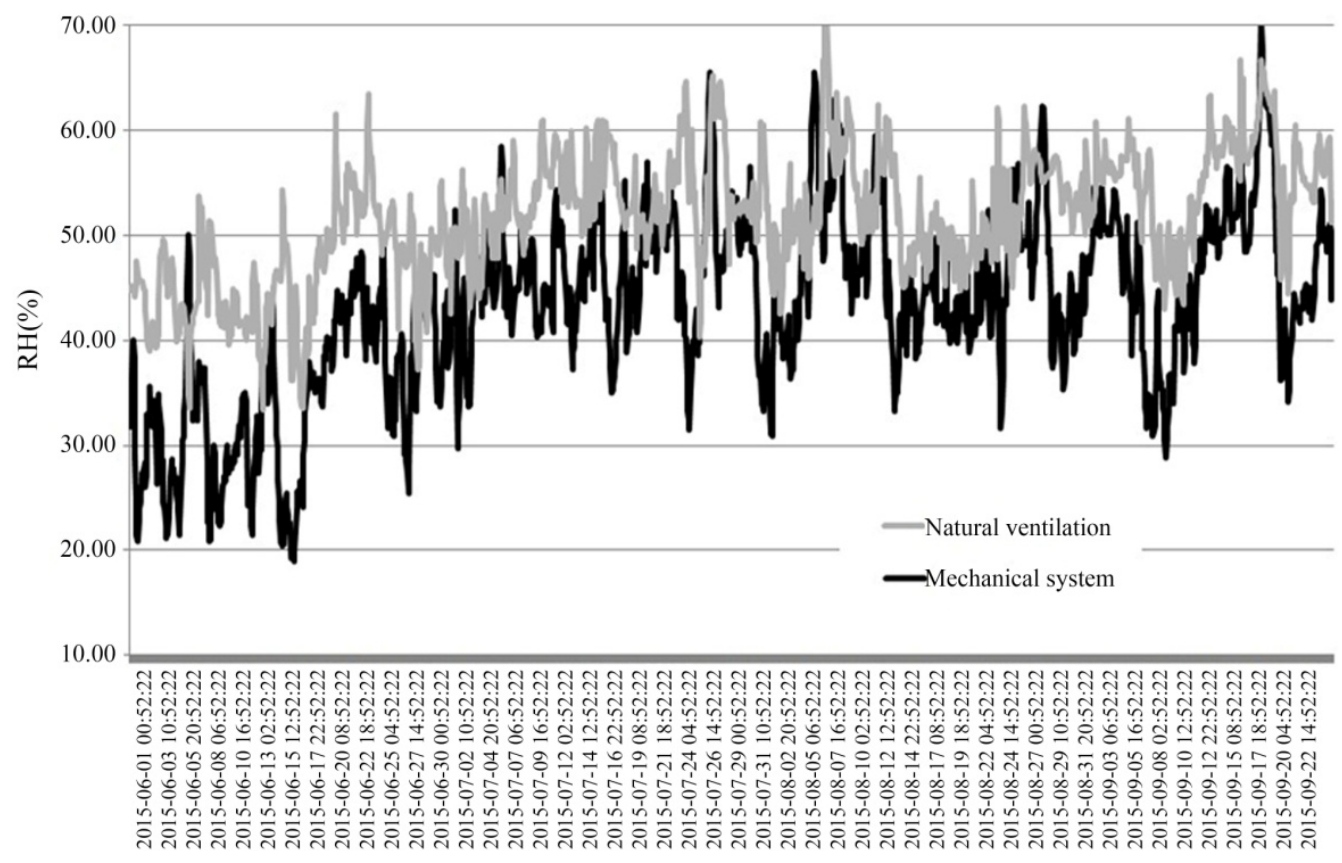

Period:1Jun-24 Sep 2015 Number of values each parameter:1 400

\begin{tabular}{|c|c|c|}
\hline Ventilation: & Mechanical & Natural \\
\hline Average & 42.31 & 51.05 \\
\hline Highest & 65.50 & 72.80 \\
\hline Lowest & 18.90 & 33.40 \\
\hline
\end{tabular}

Figure 22. Comparison of the relative humidity, RH (\%) in two buildings, one with mechanical ventilation and the other with natural draft for the period 1 June-24 September 2015. The buildings are located in central Sweden.

3) Lower relative humidity than $20 \%$ occurs at the end of November in the building with the mechanical ventilated system, while in the building with natural ventilation system the relative humidity at no time falls below this level. The mechanical system obtains once a more stable RH level of $20 \%$ at the end of April/May. Here's a significant difference identified between the two different ventilation solutions. During five months, that is $42 \%$ of the season, the RH level is more regularly above $20 \%$ with a lowest level of $10 \%$ with the mechanical ventilation system. Regarding the natural ventilated building the RH level is never below $20 \%$, but is the lowest $24.30 \%$.

One example is the Swedish requirement that the carbon dioxide level indoors only during short periods is allowed to exceed $1000 \mathrm{ppm}$, which creates big problems. Local authorities require that the carbon dioxide level of $1000 \mathrm{ppm}$ may not be exceeded and treats it as a legal requirement, even though it represents only an indicator of ventilation. Ventilation systems are in fact designed to not exceed this level. When more people than before will be housed in the premises, thus increased air flows are required which then causes the air to further dry out that and even lower RH levels are created. When problems arise for users concerning the indoor environment, it is common that the authorities immediately draws attention to the ventilation system and require increased airflows. If the building has a natural ventilation system, it is highly likely that the authority submits to the property owner to install a mechanical ventilation system with flows based on the parameter of carbon dioxide with a maximum permitted level of $1000 \mathrm{ppm}$. [57]. Survey Studies show that $72 \%$ of the employees feel that the air is too dry during the winter months, while the corresponding figure for the summer period is $40 \%$ [3]. This study shows that the perceived situation can be supported by physical measurements of the current environment. The results indicate that mechanical ventilation in buildings affects the indoor environment negatively with respect to human health during most time of the year.

\section{Conclusion}

The conclusions of the study show that mechanical ventilation, with respect to human health, has a negative im- 
pact on the indoor environment during much of the year. The results are illustrative and given what is described in Chapter 2 and in Figure 2, it is an important issue to clarify how human health is affected by staying for longer periods and during much of the day in environments with these various conditions. The situation is even more pronounced during the winter months and it is documented that the incidence of respiratory infections increases in the winter when people are exposed to long periods of low RH level indoors [2] [16] [19] [58]-[63]. However, given the link between RH level and health disorders, the conclusion is that the low RH levels prevailing in today's buildings must be taken into consideration and given the right conditions. The situation regarding the level of relative humidity must be highlighted and addressed in an entirely different way than what is happening today. Escalating complaints about health problems due to staying in a particular indoor environment and the problem known as the "Sick-Building" problem are constantly discussed in today's modern society (see what is described on the website of the Work Environment Authority theme page, sick buildings) [64]. Despite these statements, and that the problem situation only seems to increase, the authorities and others don't consider the parameter relative humidity from a health perspective. The mechanically ventilated system creates, from a health perspective, a very low relative humidity, and this fact must be taken into consideration for the existing systems as well as the planning of new ventilation systems. It is necessary in view of the Swedish climate conditions that henceforth, consider the relative humidity in calculations and installation of ventilation systems. An important national issue to come to terms with the dry indoor air is the authority requirement for ventilation flows. This requirement is based on maintaining a carbon dioxide level that only rarely exceeds 1000 ppm [57] which governs the ventilation design. This situation dilutes the negative effect on the relative humidity and further dries out the indoor air. This requirement must be questioned as it has been shown that it is based on inadequately substantiated materials from the authorities [65] [66] and where the corresponding level in the EU is $5000 \mathrm{ppm}$ [67]. For direct health effects the level of carbon dioxide has to be significantly higher, for example first at a 30-minute exposure at 50,000 ppm produces signs of intoxication [68].

\section{References}

[1] Alsmo, C. and Alsmo, T. (2013) A Study of Hygiene in Swedish Schools and Pre-Schools-Sources of Air Pollution. Journal of Environmental Protection, 4, 1349-1359.

[2] Arundel, A.V., Sterling, E.M., Biggin J.H. and Sterling, T.D. (1986) Indirect Health Effects of Relative Humidity in Indoor Environments. Environmental Health Perspectives, 65, 351-356.

[3] (2014) Myc-Tech AB, the Town Hall, Falu Municipality, Social Care Administrations. Survey Report 2014-11-25, info@myctech.com.

[4] (2011) Public Health Agency of Sweden and the Swedish Work Environment Authority. http://www.folkhalsomyndigheten.se/amnesomraden/halsoskydd-och-miljohalsa/inomhusmiljo/temperatur/ https://www.av.se/inomhusmiljo/temperatur-och-klimat/ https://www.av.se/globalassets/filer/publikationer/foreskrifter/engelska/occupational-exposure-limit-values-provisionsafs2011-18.pdf

[5] La Force, F.M. (1984) Airborne Infections and Modern Building Technology. In: Berglund, B., Lindvall, T. and Sundell, J., Eds., Proceedings of the 3rd International Conference on Indoor Air Quality and Climate 1: Recent Advances in the Health Sciences and Technology, Swedish Council for Building Research, Stockholm, 109-127.

[6] Fitzgerald, J.W. (1975) Approximation Formulas for the Equilibrium Size of an Aerosol Particle as a Function of Its Dry Size and Composition and the Relative Humidity. Journal of Applied Meteorology, 14, 1044-1049. http://dx.doi.org/10.1175/1520-0450(1975)014<1044:AFFTES $>2.0 . C O ; 2$

[7] Wright, D.N., Bailey, G.D. and Hutch, M.J. (1968) Survival of Airborne Mycoplasma as Affected by Relative Humidity. Journal of Bacteriology, 95, 251-252.

[8] Flynn, D.D. and Goldberg, L.J. (1971) Effect of Relative Humidity on Aerosol Persistence of Streptococcus salivarius. Archives of Environmental Health, 23, 40-42. http://dx.doi.org/10.1080/00039896.1971.10665952

[9] Anderson, J.D., Dark, E.A. and Pbto, S. (1968) The Effect of Aerosolization upon Survival and Potassium Retention by Various Bacteria. Journal of General Microbiology, 52, 99-105. http://dx.doi.org/10.1099/00221287-52-1-99

[10] Rosebury, T. (1947) Experimental Airborne Infection. Williams and Wilkins, Baltimore.

[11] Webb, S.J. (1959) Factors Affecting the Viability of Airborne Bacteria. 1: Bacteria Aerosolized from Distilled Water. Canadian Journal of Microbiology, 5, 649-669. http://dx.doi.org/10.1139/m59-079

[12] Couch, R.B. (1981) Viruses and Indoor Air Pollution. Bulletin of the New York Academy of Medicine, 57, 907-921.

[13] Langmuir, A.D. (1980) Changing Concepts of Airborne Infection of Acute Contagious Diseases: A Reconsideration of 
Classic Epidemiologic Theories. Annals of the New York Academy of Sciences, 353, 35-44. http://dx.doi.org/10.1111/j.1749-6632.1980.tb18903.x

[14] Moffet, H.L. (1980) Clinical Microbiology. J. B. Lippincott, Philadelphia.

[15] Gwaltney, J.M. (1980) Epidemiology of the Common Cold. Annals of the New York Academy of Sciences, 353, 54-60. http://dx.doi.org/10.1111/j.1749-6632.1980.tb18905.x

[16] Knight, V. (1980) Viruses as Agents of Airborne Contamination. Annals of the New York Academy of Sciences, 353, 147-156. http://dx.doi.org/10.1111/j.1749-6632.1980.tb18917.x

[17] Miller, W.S. and Artenstein, M.S. (1967) Aerosol Stability of Three Acute Respiratory Disease Viruses. Experimental Biology and Medicine, 125, 222-227. http://dx.doi.org/10.3181/00379727-125-32054

[18] Davis, G.W., Griesemer, R.A., Shadduck, J.A. and Farrell, R.L. (1971) Effect of Relative Humidity on Dynamic Aerosols of Adenovirus 12. Journal of Applied Microbiology, 21, 676-679.

[19] Hemmes, J.H., Winkler, K.C. and Kool, S.M. (1960) Virus Survival as a Seasonal Factor in Influenza and Poliomyelitis. Nature, 188, 430-431. http://dx.doi.org/10.1038/188430a0

[20] Harper, G.J. (1961) Airborne Micro-Organisms: Survival Tests with Four Viruses. Journal of Hygiene, 59, $479-486$. http://dx.doi.org/10.1017/S0022172400039176

[21] Schulman, J.L. and Kilbourne, E.D. (1962) Airborne Transmission of Influenza Virus Infection in Mice. Nature, 195, 1129-1130. http://dx.doi.org/10.1038/1951129a0

[22] Lester Jr., W. (1948) The Influence of Relative Humidity on the Infectivity of Air-Borne Influenza a Virus (PR8Strain). Journal of Experimental Medicine, 88, 361-367. http://dx.doi.org/10.1084/jem.88.3.361

[23] Schaffer, E.L., Soergel, M.E. and Straube, D.C. (1976) Survival of Airborne Influenza Virus, Effects of Propagating Host, Relative Humidity, and Composition of Spray Fluids. Archives of Virology, 51, 263-273. http://dx.doi.org/10.1007/BF01317930

[24] Wraith, D.G., Cunnington, A.M. and Seymour, W.M. (1979) The Role and Allergenic Importance of Storage Mites in House Dust and Other Environments. Clinical \& Experimental Allergy, 9, 545-561. http://dx.doi.org/10.1111/j.1365-2222.1979.tb00478.x

[25] Korsgaard, J. (1982) Preventive Measures in House Dust Allergy. American Review of Respiratory Disease, 125, $80-84$.

[26] Arlian, L.G., Bernstein, I.L. and Gallagher, J.S. (1982) The Prevalence of House Dust Mites, Dermatophagoides spp, and Associated Environmental Conditions in Homes in Ohio. Journal of Allergy and Clinical Immunology, 69, 527532. http://dx.doi.org/10.1016/0091-6749(82)90178-6

[27] Murray, A.B. and Zuk, P. (1979) The Seasonal Variation in a Population of House Dust Mites in a North American City. Journal of Allergy and Clinical Immunology, 64, 266-269. http://dx.doi.org/10.1016/0091-6749(79)90142-8

[28] Arlan, L.G., Brandt, R.L. and Bernstein, R. (1978) Occurrence of House Dust Mites, Dermatophagoides spp. (Acari: Pyroglyphidae), during the Heating Season. Journal of Medical Entomology, 15, 35-42. http://dx.doi.org/10.1093/jmedent/15.1.35

[29] Gravesen, S. (1979) Fungi as a Cause of Allergic Disease. Allergy, 34, 135-154. http://dx.doi.org/10.1111/j.1398-9995.1979.tb01562.x

[30] English, P.T. (1980) Medical Mycology. Edward Arnold, London.

[31] NAS (National Academy of Sciences) (1981) Indoor Pollutants. National Academy Press, Washington DC.

[32] Andersen, I., Lundqvist, G.R. and Molhave, L. (1976) The Effect of Air Humidity and Sulphur Dioxide on Formaldehyde Emissions from a Construction Material (Chipboard). Holzforschung und Holzverwertung, 28, 120-121.

[33] IEC Beak Consultants Ltd. (1983) Indoor Air Quality, Cambridge Sealed Homes: A Report for Ontario Ministry of Municipal Affairs and Housing. IEC Beak, Mississauga, Ontario.

[34] Sheppard, D., Wong, W.S. and Uehora, C.F. (1981) Lower Threshold and Greater Bronchomotor Responsiveness of Asthmatic Subjects to Sulfur Dioxide. American Review of Respiratory Disease, 122, 873-878.

[35] Alaire, Y., Ulrich, C.E., Busey, W.M., Krumma, A.A. and MacFarland, H.N. (1972) Long-Term Continuous Exposures to $\mathrm{SO}_{2}$ in Cynomolgus Monkey. Archives of Environmental Health: An International Journal, 24, 115-128. http://dx.doi.org/10.1080/00039896.1972.10666060

[36] US Environmental Protection Agency (1982) Air Quality Criteria for Oxides of Nitrogen. Environmental Criteria and Assessment Office, Research Triangle Park, NC.

[37] Mueller, F., Loeb, L. and Maper, W.H. (1973) Decomposition Rates of Ozone in Living Areas. Environmental Science \& Technology, 7, 342-346. http://dx.doi.org/10.1021/es60076a003

[38] Farrell, B.R., Kerr, H.D. and Kulle, T.J. (1979) Adaptation in Human Subjects to the Effects of Inhaled Ozone after Repeated Exposure. American Review of Respiratory Disease, 119, 725-730. 
[39] Wikipedia. https://en.wikipedia.org/wiki/Relative humidity

[40] Meyer, B. (1983) Indoor Air Quality. Addison-Wesley, Reading.

[41] McIntyre, D.A. (1978) Response to Atmospheric Humidity at Comfortable Air Temperature: A Comparison of Three Experiments. Annals of Occupational Hygiene, 21, 177-190. http://dx.doi.org/10.1093/annhyg/21.2.177

[42] Eng, W.G. (1979) Survey on Eye Comfort in Aircraft: 1. Flight Attendants. Aviation, Space, and Environmental Medicine, 50, 401-404.

[43] Strauss, R.H., McFadden, E.R., Ingram, R.H., Deal, E.C. and Jaeger, J. (1978) Influence of Heat and Humidity on the Airway Obstruction Induced by Exercise in Asthma. Journal of Clinical Investigation, 61, 433-440. http://dx.doi.org/10.1172/JCI108954

[44] Lubart, J. (1962) The Common Cold and Humidity Imbalance. New York State Journal of Medicine, 62, 817-819.

[45] Lubart, J. (1979) Health Care Containment Cost. American Journal of Otolaryngology, 1, 81-83. http://dx.doi.org/10.1016/S0196-0709(79)80011-3

[46] Zeterberg, J.M. (1973) A Review of Respiratory Virology and the Spread of Virulent and Possibly Antigenic Viruses via Air Conditioning Systems. Annals of Allergy, 31, 228-234.

[47] Sale, C.S. (1971) Humidification during the Cold Weather to Assist Perennial Allergic Rhinitis Patients. Annals of Allergy, 29, 356-357.

[48] Ingelstedt, S. (1956) Studies on the Conditioning of Air in the Respiratory Tract. Acta Oto-Laryngologica, 131, 1-80.

[49] Drettner, B., Falck, B. and Simon, H. (1977) Measurements of the Air Conditioning Capacity of the Nose during Normal and Pathological Conditions and Pharmacological Influence. Acta Oto-Laryngologica, 84, 266-277. http://dx.doi.org/10.3109/00016487709123966

[50] Richards, J.H. (1974) Effect of Relative Humidity on the Rheologic Properties of Bronchial Mucus. American Review of Respiratory Disease, 109, 484-486.

[51] Buckland, E.E. and Tyrrell, D.A.J. (1962) Loss of Infectivity on Drying Various Viruses. Nature, 195, 1063-1064. http://dx.doi.org/10.1038/1951063a0

[52] Moe, K. and Shirley, J.A. (1982) The Effect of Relative Humidity and Temperature on the Survival of Human Rotavirus in Faeces. Archives of Virology, 72, 179-186. http://dx.doi.org/10.1007/BF01348963

[53] Smith, E.B. (1983) Atmospheric Factors Affecting Transmission of Infections. Practitioner (UK), 227, 1667-1677.

[54] Hanel, G. (1977) Humidity Effects on Gravitational Settling and Brownian Diffusion of Atmospheric Particles. Pure and Applied Geophysics, 115, 775-797. http://dx.doi.org/10.1007/BF00881210

[55] Hatch, M.T. and Wolochow, H. (1969) Bacterial Survival, Consequences of the Airborne State. In: Dimmick, R.L. and Akers, A.B., Eds., An Introduction to Experimental Aero Biology, John Wiley and Sons Inc., New York.

[56] Alsmo, T. and Alsmo, C. (2014) Ventilation and Relative Humidity in Swedish Buildings. Journal of Environmental Protection, 5, 1022-1036. http://dx.doi.org/10.4236/jep.2014.511102

[57] Swedish Work Environment Authority. Workplace Design, Provisions AFS 2009: 2. https://www.av.se/globalassets/filer/publikationer/foreskrifter/engelska/workplace-design-provisions-afs2009-2.pdf

[58] Hope-Simpson, R.E. (1958) The Epidemiology of Non-Infectious Diseases. Journal of the Royal Society of Health, 78, 593-599.

[59] Gelperin, A. (1973) Humidification and Upper Respiratory Infection Incidence. Heating, Piping, Air Conditioning, 45, 3.

[60] Sale, C.S. (1972) Humidification to Reduce Respiratory Illnesses in Nursery School Children. Southern Medical Journal, 65, 882-885.

[61] Ritzel, G. (1966) Sozialmedizinsche Erhebungen zur Pathogenese und prophylare von Erkaltungskankheiten. Zeitschrift für Präventivmedizin, 11, 9-16. http://dx.doi.org/10.1007/BF02031776

[62] NCHS (National Center for Health Statistics) (1975) Acute Conditions, Incidence and Associated Disability, United States July 1973-June 1974. National Center for Health Statistics, DHEW Publ. No. (HRA) 76-1529, Rockville.

[63] Green, G.H. (1979) The Effect of Indoor Relative Humidity on Colds. ASHRAE Transactions, 85, 747-757.

[64] Swedish Work Environment Authority. Sick-Buildings. https://www.av.se/inomhusmiljo/inomhusmiljo-och-halsobesvar/

[65] Myc-Tech, A.B. Studie—Gränsvärden för koldioxid i byggnader, in Swedish, 2012-06-27. info@myctech.com

[66] National Research Council Canada. Indoor Air Quality Guidelines and Standards, RR-204, March 2005.

[67] EU (91/322/EEG). http://eurlex.europa.eu/LexUriServ/LexUriServ.do?uri=DD:05:05:31991L0322

[68] The National Institute for Occupational Safety and Health (NIOSH). http://www.cdc.gov/niosh/idlh/124389.html 